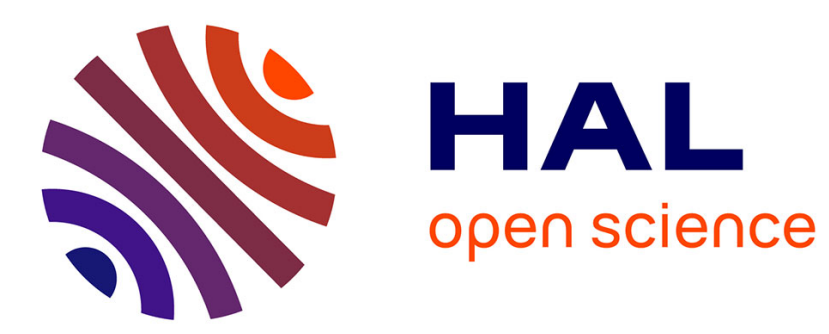

\title{
Mobility of major-, minor- and trace elements in solutions of a planosolic soil: Distribution and controlling factors
}

\author{
Aurélie Pelfrêne, Nathalie Gassama, D. Grimaud
}

\section{To cite this version:}

Aurélie Pelfrêne, Nathalie Gassama, D. Grimaud. Mobility of major-, minor- and trace elements in solutions of a planosolic soil: Distribution and controlling factors. Applied Geochemistry, 2009, 24 (1), pp.96-105. 10.1016/j.apgeochem.2008.11.006 . insu-00409650

\section{HAL Id: insu-00409650 \\ https://hal-insu.archives-ouvertes.fr/insu-00409650}

Submitted on 7 Sep 2009

HAL is a multi-disciplinary open access archive for the deposit and dissemination of scientific research documents, whether they are published or not. The documents may come from teaching and research institutions in France or abroad, or from public or private research centers.
L'archive ouverte pluridisciplinaire HAL, est destinée au dépôt et à la diffusion de documents scientifiques de niveau recherche, publiés ou non, émanant des établissements d'enseignement et de recherche français ou étrangers, des laboratoires publics ou privés. 


\title{
Mobility of major-, minor- and trace elements in solutions of a planosolic soil: distribution and controlling factors
}

\author{
A. Pelfrêne ${ }^{*}$, N. Gassama and D. Grimaud \\ ISTO-UMR CNRS 6113, Université François Rabelais Tours, UFR Sciences et Techniques, Parc de \\ Grandmont, 37200 Tours, France
}

\begin{abstract}
Subsurface waters circulating in an unpolluted soil of a planosolic horizon (Massif Central, France) were studied in order to determine their physico-chemical characteristics. Three water sampling sites were chosen along a toposequence according to topography. For each site, two piezometers were placed above and in the gravely and concretion-rich horizon (Fe- and Mn- oxyhydroxides). Concentrations of major-, minor(cations, anions, iron, manganese, phosphorus, silica) and trace elements (Al, Cd, Co, $\mathrm{Cr}, \mathrm{Cu}, \mathrm{Ni}, \mathrm{Pb}, \mathrm{Zn}, \mathrm{U})$ were monitored on bulk and filtered water $(0.45 \mu \mathrm{m})$ to study both the particulate and the dissolved components, from 2004 to 2006, during the soil saturation period (i.e. from November to May).

Chemical characteristics of soil solutions provide evidence for various chemical water compositions and for time variations of the water quality, pointing out that the hydrodynamic and chemical reactivity in the solution is different for the three sites. Calculations of pe values allow to give an information about a range of the redox state of soil solutions. The pe ranges are different for each piezometer but correspond to anoxic solution. For all piezometers, distribution between the dissolved and the particulate fraction and correlations between the various elements in the soil solutions indicate that: (i) $\mathrm{Al}$ and $\mathrm{Fe}$ show similar behaviour, (ii) $\mathrm{Al}$ is mainly present as oxyhydroxides and (iii) some trace metals are mainly associated with particles which
\end{abstract}

\footnotetext{
* Corresponding author

E-mail address: aurelie.pelfrene@etu.univ-tours.fr (A. Pelfrêne)
} 
have a mixed nature. The impact of the concretion-rich horizon is noticed both on the nature of particles and on the speciation of trace metals and could be explained by the hydrodynamic and chemical reactivity of the circulating solution. Very few correlations exist between elements in the dissolved phase.

\section{Keywords}

Soil solutions, Planosol, trace metals, speciation, Al, Fe, controlling factors, mobility.

\section{Introduction}

Trace metals are naturally present in soils reflecting their occurrence in the parent material. They are, however, also present as environmental contaminants, particularly since soil pollution has become a major problem due to anthropogenic activities. As a consequence, assessment of this pollution requires a good knowledge of the distribution of trace metals in unpolluted soils, the so-called pedogeochemical background level. The total concentration of trace metal is not the only factor to be considered to assess toxicity hazard. The speciation of trace metals (i.e., the distribution of their physicochemical forms) ultimately determines their bioavailability and their mobility in the soil (Alloway, 1990). These characteristics of trace metals in soils, sediments and aquatic systems depend largely upon their interaction with organic compounds and/or minerals like clays, hydrous oxides of Fe, $\mathrm{Al}$ and Mn (Stumm and Morgan, 1970). Adsorption of trace metals onto solid compounds and associated surface coatings is considered very important in controlling metal activity (Sposito, 1989; Sigg, 1992; Alloway, 1990). Moreover, $\mathrm{pH}$ and redox conditions are factors that also affect the chemistry of metals in soils, and their uptake by organisms (Singh and Steinnes, 1994). 
Planosols are characterised by a vertical succession of clay-poor horizons overlying a clay-rich horizon that drastically restricts the vertical flow of water and induces the occurrence of a seasonal water table (Baize, 1989). According to the water hydrodynamic during the year, oxide concretions may develop at the base of the last horizon. In this horizon, trace elements can be accumulated or released depending on the dynamic of oxide formation/dissolution.

The Planosol studied here is developed from metamorphic parent material. Naturally rich in trace elements due to the geology, this soil is subject to seasonal water saturation during winter and spring (Salvador-Blanes, 2002). In this hydromorphic soil, water circulation, notably lateral underflow above clayey horizons, can involve specific chemical reactions and transfers (Bourrié et al., 1994). Soil solutions were collected above and in a gravely and concretion-rich (Fe and Mn oxides) horizon, in order to assess its impact on the distribution of trace metals in the soil waters. The objectives of this paper are (i) to determine the range, distribution and behaviour of major-, minorand trace elements in these unpolluted soil solutions, (ii) to identify the main physical and chemical controlling factors of their distribution, and (iii) to assess the impact of the concretion-rich horizon on the trace metal distribution. The soil solutions have been monitored for three years. Concentrations both in the soluble and in the particulate fraction have been considered. Redox conditions have been assessed to provide evidence for particular mechanisms. The study of chemical speciation of some trace elements has been developed in a further paper (Pelfrêne et al., 2008).

\section{Environmental settings}

The study area is located on the Aigurande plateau in the northern part of the Massif Central (France). The substratum is composed of Paleozoic metamorphic formations 
(gneiss and amphibolite) and intrusive granitic rocks (Quenardel and Rolin, 1984). The area is a grassland in a hedged farmland district. The studied soil is a Planosol developed from gneissic parent material. Planosols are characterized by the vertical succession of horizons (Fig. 1a). The upper horizon (sandy and organic-rich horizon) is allochthonous and derived from colluvial materials of amphibolitic (site 1, piezometers 1a and $1 \mathrm{~b}$ ) and gneissic (sites 2 and 3, piezometers 2a, 2b, 3a and 3b) origin (SalvadorBlanes et al., 2001) (Fig. 1b). The gravelly and concretion-rich horizon below comprises concretions which are mainly composed of several types of cements (Fe-rich, Si- and Al-rich, Mn-rich and Ti-rich) surrounding grains of quartz, feldspars, micas and accessory minerals (Salvador-Blanes, 2002; Cornu et al., 2005). The deeper horizons (a silty horizon and alterite) are developed in gneissic material (mainly quartz with feldspars, micas and clay minerals) (Salvador-Blanes, 2002). The horizons are waterlogged during winter and spring. The mean annual rainfall in the area was 872 , 667 and $772 \mathrm{~mm}$ for 2004, 2005 and 2006, respectively. The main rainfall occurs between December and March.

\section{Sampling and analytical methods}

Three water sampling sites were chosen along a toposequence according to topography (Fig. 1). Two piezometers were placed in each site, in November 2003: above (noted 1a, 2a, 3a respectively for sites 1,2 and 3 ) and in (noted $1 \mathrm{~b}, 2 \mathrm{~b}$ and $3 \mathrm{~b}$ respectively for sites 1, 2 and 3) the gravelly and concretion-rich horizon. Piezometers were made of a strainer (20 cm height) in order to collect free water circulating in the soil horizon. Soil solution samples were collected from March 2004 to May 2006 (every 15 days) during the soil saturation period (i.e. from November to May). In 2004, sampling began in March in order to allow the soil to reach equilibrium. Bulk and filtered water were 
sampled to study both the particulate and the dissolved phases. The concentrations of the particulate fraction were determined by subtracting concentration measured in the bulk solution from concentration measured in the dissolved fraction. Soil waters were filtered in the field through $0.45 \mu \mathrm{m}$ membrane filters (acetate of cellulose) with a frontal-flow system in order to separate dissolved and particulate fractions. Prior to use, each membrane was rinsed with deionized water (18 M $\Omega)$ and then with the sample. Filtered and bulk water samples were acidified to $\mathrm{pH} \approx 2$ with Suprapur ${ }^{\circledR}$ grade nitric acid for aliquots intended for cation, phosphorus, dissolved silica, TOC, DOC and trace metal analysis. The samples were stored in previously washed polypropylene containers. Physico-chemical parameters (temperature, $\mathrm{pH}$ and electrical conductivity C) were measured in the field. Alkalinity was measured the same evening by the Gran method (Gran, 1950) with a $\mathrm{HCl}$ solution. Bicarbonate concentrations were calculated considering alkalinity mainly due to carbonate. Total organic C (TOC, on unfiltered water samples) and dissolved organic $\mathrm{C}$ (DOC) were determined by using a $\mathrm{C}$ analyzer (Shimadzu TOC-V $\mathrm{VSSH}_{\mathrm{C}}$, NPOC method). Particulate organic C (POC) was obtained by difference between TOC and DOC. Calcium and $\mathrm{Mg}$, in the bulk and filtered waters $(0.45 \mu \mathrm{m})$, were determined by flame atomic absorption spectrometry, and $\mathrm{Na}$ and $\mathrm{K}$ by flame atomic emission spectrometry. Chloride, $\mathrm{F}^{-}, \mathrm{NO}_{3}{ }^{-}$and $\mathrm{SO}_{4}{ }^{2-}$ in the filtered waters were measured by ionic chromatography. Total and dissolved P and Si were measured by molecular spectrometry.

Iron and $\mathrm{Mn}$ in the bulk and filtered waters were measured by graphite furnace atomic absorption spectrometry. Trace elements ( $\mathrm{Al}, \mathrm{Cd}, \mathrm{Co}, \mathrm{Cr}, \mathrm{Cu}, \mathrm{Ni}, \mathrm{Pb}, \mathrm{Zn}$ and $\mathrm{U}$ ) in the different fractions were measured by ICP-MS. Bulk solutions were analyzed by ICPMS after successive $\mathrm{HNO}_{3}$ digestions in order to destroy organic matter and to dissolve amorphous particles. However, the clayey fraction and other silicates were not 
destroyed. Therefore, the particulate fraction corresponds to amorphous particles (plus carbonates) and ions adsorbed on the clay minerals.

All samples exhibited a charge imbalance lower than $10 \%$.

Blank filters were run out in the field to check for possible contamination. Deionized water passed through filters was also analyzed. Blank tests showed that the filtration introduces insignificant levels of contamination for all the elements of interest.

\section{Results}

\subsection{Major elements and nutrients}

In the dissolved fraction, wide ranges of concentrations are recorded for the three sites from 2004 to 2006 for major- and minor-elements (Table 1, exhaustive data are available in Pelfrêne, 2008). In $1 \mathrm{a}$ and $1 \mathrm{~b}$, low conductivities (79 \pm 12 and $85 \pm 16$ $\mu \mathrm{S} / \mathrm{cm}$, respectively), low and stable major element concentrations and low nutrient $\left(\mathrm{NO}_{3}{ }^{-}, \mathrm{P}\right.$ and $\left.\mathrm{Si}\right)$ concentrations are observed. For the site 2, conductivities are higher $(269 \pm 31 \mu \mathrm{S} / \mathrm{cm}$ in $2 \mathrm{a}$ and $248 \pm 41 \mu \mathrm{S} / \mathrm{cm}$ in $2 \mathrm{~b})$ and important variations of nutrient concentrations are noticed $\left(\mathrm{NO}_{3}{ }^{-}: 260.5 \pm 360.2 \mu \mathrm{M}\right.$ in $2 \mathrm{a}$ and $129.6 \pm 149.1 \mu \mathrm{M}$ in $\left.2 \mathrm{~b}\right)$. In $3 \mathrm{a}$ and $3 \mathrm{~b}$, conductivities are highest $(295 \pm 62 \mu \mathrm{S} / \mathrm{cm}$ in $3 \mathrm{a}$ and $322 \pm 74 \mu \mathrm{S} / \mathrm{cm}$ in 3b) and important variations of major elements $\left(\mathrm{K}^{+}: 38.8 \pm 29.4 \mu \mathrm{M}\right.$ in $3 \mathrm{a}$ and $17.4 \pm$ $14.9 \mu \mathrm{M}$ in $3 \mathrm{~b})$ and nutrients $\left(\mathrm{NO}_{3}{ }^{-}: 10.6 \pm 10.8 \mu \mathrm{M}\right.$ in $3 \mathrm{a}$ and $21.0 \pm 39.7 \mu \mathrm{M}$ in $\left.3 \mathrm{~b}\right)$ are observed.

Concentrations of major cations do not differ significantly between sites except $\mathrm{Ca}^{2+}$, which is higher in 1a and $1 \mathrm{~b}$ (Fig. 2). This Ca-rich content could be explained by the origin of colluvial materials. Amphiboles which are the main minerals of amphibolites might cause high $\mathrm{Ca}$ values at sites $1 \mathrm{a}$ and $\mathrm{b}$. Low values for $\mathrm{Ca}$ at sites 2 and 3 indicate 
a different circulation system, perhaps via lateral input of water from a low $\mathrm{Ca}$ source (gneisses).

For each piezometer, the cation concentrations do not show important temporal evolution (less than 20\%, Fig. 2). Results for the anion distribution are different (Table 2). Strong temporal variations are observed for (i) $\mathrm{HCO}_{3}{ }^{-}$, mainly in $3 \mathrm{a}$ and $3 \mathrm{~b}$, and (ii) $\mathrm{NO}_{3}{ }^{-}$and $\Sigma\left(\mathrm{Cl}^{-}+\mathrm{SO}_{4}{ }^{2-}\right)$ in $2 \mathrm{a}, 2 \mathrm{~b}, 3 \mathrm{a}$ and $3 \mathrm{~b}$. For $3 \mathrm{~b}$ in $2005, \mathrm{HCO}_{3}{ }^{-}$concentrations were high $(3.70 \pm 0.23 \mathrm{mM})$, and no correlation exists between $\mathrm{HCO}_{3}{ }^{-}$and $\mathrm{Ca}^{2+}$. Because waters circulate in crystalline rocks, $\mathrm{HCO}_{3}{ }^{-}$cannot originate from bedrock weathering. During this period, concentrations of some other elements $(\mathrm{Ca}, \mathrm{Na}, \mathrm{Mn}$ and Fe) are also high. Calculations show that soil solutions are in a thermodynamic equilibrium with a $\mathrm{pCO}_{2}\left(5.11 \times 10^{-2}\right.$ atm in 2005) higher than medium $\mathrm{pCO}_{2}(2004-$ $\left.2006,1.72 \times 10^{-2} \mathrm{~atm}\right)$.

For sites 2 and $3 \mathrm{NO}_{3}{ }^{-}$concentrations exhibit strong temporal variations (Table 2), with low values during spring, indicating vegetation assimilation, absorption and/or denitrification.

\subsection{Fe, Mn, Al, Si and organic matter}

For each piezometer, results on soluble/particulate form distributions (Table 3) show that $\mathrm{Fe}$ (excepted in 1a) and $\mathrm{Al}$ are mainly associated with particles, while $\mathrm{Mn}, \mathrm{Si}$ and organic matter have an ubiquitous behaviour. The particulate phases in the soil waters are rich in $\mathrm{Fe}, \mathrm{Al}$ and $\mathrm{Si}$. The composition of particles varies spatially and temporally. In the sites 1 and 3, particles are richer in Si. Silicium percentage increases from March 2004 to May 2006, while Fe and Al decrease in all sites. 
In the dissolved and particulate fraction, $\mathrm{Al}$ is not linked to $\mathrm{Si}$ (no correlation between these elements is recorded), indicating that the source of Al may not be aluminosilicate minerals but rather $\mathrm{Al}$ oxyhydroxides.

Correlations between $\mathrm{Al}, \mathrm{Fe}, \mathrm{Mg}$ and $\mathrm{POC}$ are observed in the particulate fraction. These relationships will be discussed site by site.

In January 2005, soil waters at site $3 \mathrm{~b}$ exhibited more reducing characteristics with a maximum recorded concentration of dissolved $\mathrm{Fe}\left(4.31 \times 10^{-5} \mathrm{~mol} / \mathrm{L}\right)$ and dissolved $\mathrm{Mn}$ $\left(3.82 \times 10^{-5} \mathrm{~mol} / \mathrm{L}\right)($ Table 2$)$.

\subsection{Trace elements}

Concentrations of trace elements are presented in Table 4.

\subsubsection{Site 1}

In the particulate fraction, three groups of trace elements can be distinguished. In $1 \mathrm{a}, \mathrm{Cr}$ is linked to $\mathrm{Al}\left(\mathrm{R}^{2}=0.986\right) ; \mathrm{Co}, \mathrm{Pb}$ and $\mathrm{Zn}$ are strongly linked to $\mathrm{Fe}\left(\mathrm{R}^{2}=0.999 ; 0.992\right.$ and 0.992 respectively). $\mathrm{In} \mathrm{1b}, \mathrm{Co}, \mathrm{Cr}, \mathrm{Cu}, \mathrm{Ni}, \mathrm{Pb}, \mathrm{U}$ and $\mathrm{Zn}$ are linked to $\mathrm{Mg}, \mathrm{Fe}$ and $\mathrm{Al}$ (Table 5). No relationship between trace metals and organic matter is recorded. In the dissolved fraction, it was observed that (1) in $1 \mathrm{a}$ and $1 \mathrm{~b}$, some elements are linked to $\mathrm{HCO}_{3}{ }^{-}$; the relationships are particularly significant for $\mathrm{Ca}\left(\mathrm{R}^{2}=0.726\right.$ in 1a and 0.813 in $1 b), \operatorname{Mg}\left(R^{2}=0.831\right.$ in 1a and 0.902 in $\left.1 b\right), \operatorname{Sr}\left(R^{2}=0.868\right.$ in $1 \mathrm{a}$ and 0.907 in 1b) and $\mathrm{Ba}\left(\mathrm{R}^{2}=0.874\right.$ in $1 \mathrm{a}$ and 0.813 in $\left.1 \mathrm{~b}\right)$; (2) in 1a and $1 \mathrm{~b}, \mathrm{Cr}$ is linked to $\mathrm{Al}\left(\mathrm{R}^{2}=\right.$ 0.986 and 0.906 , respectively).

The correlations between $\mathrm{HCO}_{3}{ }^{-}$and some elements $(\mathrm{Ca}, \mathrm{Mg}, \mathrm{Sr}$ and $\mathrm{Ba})$ could indicate that these elements are linked to carbonate dissolution.

Chromium is linked to Al both in the dissolved and particulate fraction (1b). 
In $1 \mathrm{~b}$, the similar behaviour of $\mathrm{Al}, \mathrm{Fe}$ and $\mathrm{Mg}$ suggests that these elements are controlled by the same mechanism. If $\mathrm{Al}$ is present as $\mathrm{Al}$ oxyhydroxide, $\mathrm{Fe}$ as $\mathrm{Fe}$ oxyhydroxide, $\mathrm{Mg}$ as clay, which are particles exhibiting different properties, this result could also suggest the presence of mixed particles, which is corroborated by a link between $\mathrm{Al}$ and $\mathrm{Mg}\left(\mathrm{R}^{2}=0.978\right)$.

The absence of correlation between organic matter content and trace metals could be attributed to the fact that the reactive fraction of the organic matter could not be assessed in the relationship (Harter, 1983; McBride et al., 1997).

\subsubsection{Site 2}

In the particulate fraction, six groups of trace elements can be distinguished. In $2 \mathrm{a}, \mathrm{Cr}$, Ni and $\mathrm{U}$ are linked to $\mathrm{Al}\left(\mathrm{R}^{2}=0.929 ; 0.903 ; 0.934\right.$ respectively); Cd is linked to POC $\left(\mathrm{R}^{2}=0.719\right)$. In $2 \mathrm{~b}, \mathrm{Co}, \mathrm{Cu}, \mathrm{Pb}, \mathrm{U}, \mathrm{Zn}$ are linked to $\mathrm{Mg}$ (Table 6); $\mathrm{Al}, \mathrm{Cr}, \mathrm{Cu}, \mathrm{Ni}, \mathrm{Pb}, \mathrm{U}$ are strongly correlated with $\mathrm{Fe}$ (Fig. 3); $\mathrm{Co}, \mathrm{Cr}, \mathrm{Cu}, \mathrm{Ni}, \mathrm{Pb}, \mathrm{U}, \mathrm{Zn}$ are linked to $\mathrm{Al}$ and POC (Table 7).

No relationship is observed in the dissolved fraction.

In $2 \mathrm{~b}$, relationships between some trace elements and $\mathrm{Mg}$ and/or $\mathrm{Al}$ and $\mathrm{Fe}$ and/or POC suggest mixed particles made of a combination of clay + Al-Fe oxyhydroxide + POC are involved in the mobilization of these elements. Observed relationships between POC and $\mathrm{Fe}\left(\mathrm{R}^{2}=0.865\right), \mathrm{Mg}$ and $\mathrm{Fe}\left(\mathrm{R}^{2}=0.948\right), \mathrm{Al}$ and $\mathrm{Mg}\left(\mathrm{R}^{2}=0.978\right)$ and POC and $\mathrm{Al}\left(\mathrm{R}^{2}=0.952\right)$ corroborate this hypothesis.

No evidence of mixed particles is recorded in $2 \mathrm{a}$.

\subsubsection{Site 3}

In the particulate fraction, the correlation diagrams delineate several groups of elements. In $3 \mathrm{a}, \mathrm{Pb}$ and $\mathrm{U}$ are correlated with $\mathrm{Si}\left(\mathrm{R}^{2}=0.850\right.$ and 0.888 respectively); $\mathrm{Al}, \mathrm{Co}$ and $\mathrm{Cr}$ are correlated with $\mathrm{Mg}\left(\mathrm{R}^{2}=0.943 ; 0.900\right.$ and 0.919 respectively); $\mathrm{Co}, \mathrm{Cr}, \mathrm{Pb}$ and $\mathrm{Zn}$ are strongly correlated with $\mathrm{Al}$ (Table 8). In 3b, no correlation exists between $\mathrm{Si}, \mathrm{Mg}$ 
and metals; Co, Cr, Cu, Ni, U and Zn are correlated with Fe (Fig. 4) and Al (except Ni) (Table 8); $\mathrm{Cr}$ and $\mathrm{Cu}$ are correlated with POC $\left(\mathrm{R}^{2}=0.980\right.$ and 0.987 , respectively). In the dissolved fraction, in $3 \mathrm{a}, \mathrm{Co}$ and $\mathrm{Mn}$ are correlated with $\mathrm{Fe}\left(\mathrm{R}^{2}=0.947\right.$ and 0.964, respectively), and in $3 \mathrm{~b}, \mathrm{Cu}, \mathrm{Mn}, \mathrm{Sr}$ and $\mathrm{U}$ are correlated with $\mathrm{HCO}_{3}{ }^{-}$and $\mathrm{Ca}$ (Table 9).

In 3a, some trace metals exhibit interaction with clay and $\mathrm{Al}$ oxyhydroxide where a relationship between $\mathrm{Al}$ and $\mathrm{Mg}\left(\mathrm{R}^{2}=0.943\right)$ is recorded in particles. In $3 b$, observed relationships between POC and $\mathrm{Fe}\left(\mathrm{R}^{2}=0.985\right), \mathrm{Al}$ and $\mathrm{Mg}\left(\mathrm{R}^{2}=0.971\right)$, and $\mathrm{Al}$ and Fe $\left(\mathrm{R}^{2}=0.940\right)$ suggest mixed particles made of a combination of clay $+\mathrm{Al}-\mathrm{Fe}$ oxyhydroxides + POC. But here trace metals exhibit interaction mainly with $\mathrm{Al}$ and Fe oxyhydroxides. Also, in site 3, mixed particles can also assumed but with different composition and/or reactivity (interaction with carbonate in solution for $3 b$ ) according to horizon.

\section{Discussion}

\subsection{Chemical characteristics of soil solution and water circulation}

Waters circulating in sites 2 and 3 are more mineralized than that in the site 1 . The soil solution composition seems to depend on the water residence time. The Ca-rich content in the site 1 may evidence that water circulating in the sites 2 and 3 does not mainly come from vertical infiltration but rather from lateral flow.

Between March 2004 to May 2006, for sites 2 and 3, some constituents $\left(\mathrm{NO}_{3}{ }^{-}, \mathrm{Cl}^{-}, \mathrm{SO}_{4}{ }^{2-}\right.$ $\left., \mathrm{HCO}_{3}{ }^{-}, \mathrm{Ca}^{2+}, \mathrm{Fe}, \mathrm{Mn}\right)$ exhibit interesting temporal patterns.

Chloride and $\mathrm{SO}_{4}{ }^{2-}$ variation could be linked to the hydrodynamic of the soil solution, which is controlled both by the effective rainfall variations and vegetation uptake. During high rainfall, transfer and dilution processes can occur. Autumn rainfall flushes 
evaporated and thus concentrated superficial waters, whereas winter rainfall causes dilution.

From November 2004 to May 2005, the high $\mathrm{pCO}_{2}$ recorded in site 3 may indicate that confined waters circulated in the studied horizon. This could be explained by a shoaling of the water table. This explanation has also been proposed by Alberic et al. (Unpublished study), based on redox data.

The reduction in $\mathrm{NO}_{3}{ }^{-}$content recorded at sites 2 and 3 in spring 2005 and 2006 may be linked to denitrification, because the concentration of dissolved $\mathrm{Fe}$ and mainly dissolved Mn increase at this same time.

The subsurface water circulation pattern is not in agreement with topography. Site 2 seems to receive mainly lateral waters. Site 3 water may originate from site 2 , from the side, or from a confined aquifer. Also, the evolution of trace element behaviour upstream/downstream cannot be discounted.

\subsection{Range of the redox state of soil solutions}

Redox reactions play an important role in the chemistry of natural water systems and influence the mobility and availability of many elements. In this work, the range of pe values in soil solutions was calculated in order to determine the degree of oxidation of trace metals and to study the links between metals and Fe/Mn/Al oxyhydroxides. Temporary waterlogging of soils may cause the redox potential to decrease.

In the soil solutions, $\mathrm{Fe}$ and $\mathrm{Mn}$ are redox sensitive elements and can be used to evaluate the pe values, which were calculated using a pe-pH diagram, considering different redox couples and solids. Here pe-pH diagrams were constructed considering the following species: $\mathrm{Fe}^{2+}, \mathrm{Fe}^{3+}, \mathrm{FeOH}^{2+}, \mathrm{Fe}(\mathrm{OH})_{2}, \mathrm{FeOOH}$ and $\mathrm{Mn}^{2+}, \mathrm{MnO}_{2}$. For the Fe pe-pH diagram, it was considered that soluble $\mathrm{Fe}$ was at equilibrium with $\mathrm{FeOOH}$ 
$\left(\mathrm{pKs}=-1\right.$, Michard, 1989) and not with $\mathrm{Fe}(\mathrm{OH})_{3}$ because of Fe-minerals (mainly goethite) present in the studied soil (Cornu et al., 2005) (for Fe(III) solid). The highest calculated pe values for Fe and $\mathrm{Mn}$ are +1.3 and +2.2 , respectively, and the lowest are 6.0 and -2.5 , respectively. For all piezometers, $\mathrm{Mn}$ pe calculated values are higher than Fe pe. Differences of up to 1.2-2.5 (pe) are observed between Fe and Mn redox couples, indicating a disequilibrium in the soil solutions. The redox reaction rates are typically slow. In this dynamic system where several redox reactions can occur simultaneously, redox species can hardly reach an equilibrium. Nevertheless, these calculations provide a range of the redox states of soil solutions.

The pe ranges are different for each piezometer (Fig. 5), but correspond to anoxic conditions (pe values $<+2.5$ ) from November to May (for each year). When pe $<0$, electrons are available for $\mathrm{SO}_{4}{ }^{2-}$ reduction. In this case, typical products in soil solution are $\mathrm{H}_{2} \mathrm{~S}$, bisulphide $\left(\mathrm{HS}^{-}\right)$or thiosulphates $\left(\mathrm{S}_{2} \mathrm{O}_{3}{ }^{-}\right)$ions. However, in the field, the typical smell of these products was only present for site 3 . The pe values for site 3 are lower than for site 2 and site 1. Upstream (site 1), waters are recently infiltrated and contain little $\mathrm{O}_{2}$. Then, during water circulation in the soil (site 2 and then site 3), mineral reactions result in a decrease in $\mathrm{O}_{2}$ content and pe values.

\subsection{Behaviour of trace elements}

Binary correlations provide evidence when one mechanism prevails in the regulation of an element's behaviour. If several mechanisms with the same impact are involved, they cannot be identified.

At the scale of the 3 sites, various behaviours are highlighted, notably: (i) good correlations between $\mathrm{Co}$ and $\mathrm{Mn}$ in the soluble phase $\left(\mathrm{R}^{2}=0.908\right.$; Fig. 6a), (ii) strong correlations between $\mathrm{U}$ and $\mathrm{Fe}$ in the particulate phase $\left(\mathrm{R}^{2}=0.958\right.$; Fig. $\left.6 \mathrm{~b}\right)$, (iii) some 
trace metals are mainly associated with particles (Table 4) and (iv) very few elements are correlated in the dissolved fraction. In the narrow range of calculated redox states, no difference is really noticed from site 1 to site 3, perhaps excepted for $\mathrm{Cr}$ and $\mathrm{U}$ in the particulate fraction.

The relationship between Co and Mn reflects the well-known affinity and adsorption (or co-precipitation)/desorption of Co onto amorphous $\mathrm{MnO}_{2}$. Cobalt associated with $\mathrm{Mn}$ oxide phases is probably released (or maybe reduced) when the oxides are reduced (Spencer et al., 1972; Murray, 1975). Significant correlations were also found between dissolved Co and dissolved Mn in aquatic systems by Lienemann et al. (1997). Most of the $\mathrm{Co}$ in the soils is contained in or associated with Mn in mineral form. Indeed, there is a large literature on the adsorption of cobalt by $\mathrm{MnO}_{2}$ : in soils and sediments (Means et al., 1978b; Alloway, 1990), in fresh waters (Hem et al., 1985), in lakes (Balistrieri et al., 1992) and in sea water (Knauer et al., 1982; Hem et al., 1985; Santschi, 1988; Shaw et al., 1990). Studies of adsorption of Co(II) on synthetic birnessite have been carried out too by Crowther et al. (1983). They proposed several mechanisms of Co incorporation into Mn-rich phases of minerals. In the soil solutions, co-precipitation and adsorption seem to be the mechanisms which explain the link between Co and Mn.

Some studies have shown a high sorptive capacity of $\mathrm{Mn}$ oxyhydroxides and $\mathrm{MnO}_{2}$ towards some trace metals. In various natural settings (Jenne, 1968; Carpenter et al., 1975; Robinson, 1981; Dillard et al., 1982; Lind and Hem, 1993) and in a series of laboratory experiments, many metals are closely associated with Mn oxyhydroxides, including: Zn (Balistrieri and Murray, 1986; Catts et al., 1986; Hem et al., 1987), Cu and Ni (Balistrieri et al., 1986; Hem et al., 1989), Cd (Hem et al., 1991), Pb (Catts et al., 1986); but also in deep-sea sediments ( $\mathrm{Cu}, \mathrm{Ni}, \mathrm{Pb}$ and $\mathrm{Zn})$ (Thomson et al., 1993), in sea water (Ni, Cu and V) (Shaw et al., 1990) and as coating on quartz (Manceau et al. 
2007). The importance of processes occurring at reaction sites on solid-phase surface in contact with Mn-bearing solutions has long been recognized, but these results are not observed here. In this work, redox equilibrium and oxidation kinetics of $\mathrm{Mn}$ are important factors in the speciation of trace metals.

Significant correlations exist between $\mathrm{U}$ and $\mathrm{Fe}$ in the particulate fraction. Uranium transport is dominated by $\mathrm{U}$ sorbed to Fe oxyhydroxides which are $>0.45 \mu \mathrm{m}$ in size. In spite of the dynamic redox environment expected in soil solutions, this result shows that U comprised of both U(IV) and U(VI) species. Some authors (Ragnarsdottir and Charlet, 2000) have shown that the most important species for near neutral waters are the uncharged $\mathrm{UO}_{2}(\mathrm{OH})_{2}{ }^{0}$ and $\mathrm{U}(\mathrm{OH})_{4}{ }^{0}$ species.

The trace metal concentration is governed by a number of interrelated processes, including inorganic and organic complexation, precipitation/dissolution reactions, adsorption/desorption reactions and redox reactions (Evans, 1989; Singh and Steinnes, 1994). These observed results indicate the high impact of particles on the regulation of trace mobility (Table 10). In addition, they intend to assess the mixed nature of particles. If $\mathrm{Al}$ is mainly present as oxyhydroxides (no correlation with $\mathrm{Si}$ ) its links with Mg suggest an association with clay mineral. This result is also observed for Fe. An adsorption of $\mathrm{Fe}$ and $\mathrm{Al}$ oxyhydroxides can occur on clay minerals and involves various types of binding between metals $\left(\mathrm{M}^{\mathrm{n}+}\right)$ and oxyhydroxides and/or clay minerals: (i) $\mathrm{M}^{\mathrm{n}+}$ - Al/Fe oxyhydroxides, (ii) $\mathrm{M}^{\mathrm{n}+}-$ clay minerals, and/or (iii) $\mathrm{M}^{\mathrm{n}+}-\mathrm{Al} / \mathrm{Fe}$ oxyhydroxides - clay minerals. Some authors have provided evidence for similar mechanisms. Robinson (1981) showed that the chemical properties of the Mn oxides are associated with the clay minerals. Jenne (1968) noted the probable occurrence of Fe and Mn oxides as partial coatings on other minerals (and notably clay minerals). Clay minerals and oxyhydroxide minerals have long been recognized as the main metal sorbents in soils 
(Jenne, 1968; Evans, 1989) and in aquatic systems (Förstner and Wittmann, 1979; Benjamin and Leckie, 1981; Bilinski et al., 1991).

Soil solutions were collected above and in the gravely and concretion-rich horizon, in order to assess the impact of the concretion-rich horizon on the distribution of trace metals in the soil waters. In this horizon, concretions are Fe- and Mn-rich coatings and can stabilize trace metals by adsorption or co-precipitation processes with Fe-Mn oxyhydroxides under oxidizing conditions (Jenne, 1968; Stumm and Morgan, 1996). When soils become reduced, trace metals (in soluble or particulate form) can be released into the soil solution by reductive dissolution of Fe-Mn oxyhydroxides. Much higher correlations were found between $\mathrm{Fe} / \mathrm{Al} / \mathrm{Mg}$ and/or POC and trace metals in the concretion-rich horizon. This can be linked to (i) concretion composition or (ii) hydrodynamic (reaction time between water and soil due to porosity) and chemical reactivity of the solution circulating.

\section{Conclusions}

This study highlights the distribution, behaviour and controlling factors of some trace metals in unpolluted soil solutions of a planosolic horizon and enhanced knowledge of these kinds of solution. The relationships between the different parameters and trace metals are complex and can not be related to only one parameter. However, results show Fe and Al oxyhydroxides, clay minerals and organic matter play an important role in trace metal distribution and mobility. In these weakly reductive waters, trace metals are mainly linked to particles. In addition, the concretion-rich horizon has an impact both on the trace element composition and on the particle composition, although this impact cannot be linked to the chemical distribution of the horizon. 


\section{Acknowledgments}

This work was supported by Le Conseil Régional du Centre as part of the METALOE program. We gratefully acknowledge Martine Bouhnik-Le-Coz (CAREN Géosciences Rennes) for ICP-MS analysis and Mrs Narbone (IUT Tours) for a part of AAS and AES analysis. Two anonymous reviewers supplied very useful comments. Pr. Gabriel Filippelli, Associate Editor, proposed important comments which improved the present manuscript.

\section{References}

Alloway, B.J., 1990. Soil processes and the behaviour of metals. In: Alloway, B.J. (Ed.), Heavy metals in soils, Blackie, Glasgow and London, UK, pp. 7-28.

Baize, D., 1989. Planosols in the "Champagne Humide" region, France. A multiapproach study. Pédologie, XXXIX-2, Ghent, pp. 119-151.

Balistrieri, L.S., Murray, J.W., 1986. The surface chemistry of sediments from the Panama Basin: the influence of Mn oxides on metal adsorption. Geochim. Cosmochim. Acta 50, 2235-2243.

Balistrieri, L.S., Murray, J.W., Paul, B., 1992. The biogeochemical cycling of trace metals in the water column of lake Sammamish, Washington: response to seasonally anoxic conditions. Limnol. Oceanogr. 37, 529-548.

Benjamin, M.M., Leckie, J.O., 1981. Multiple-site adsorption of $\mathrm{Cd}, \mathrm{Cu}, \mathrm{Zn}$ and $\mathrm{Pb}$ on amorphous iron oxyhydroxide. J. Colloid Interface Sci. 78, 209-221.

Bilinski, H., Kozar, S., Plavsic, M., Kwokal, Z., Branica, M., 1991. Trace metal adsorption on inorganic solid phases under estuarine conditions. Mar. Chem. 32, 225233.

Bourrié, G., Maître, V., Curmi, P., 1994. Mise en évidence de deux dynamiques saisonnières du fer dans les sols hydromorphes en climat tempéré. C. R. Acad. Sci. Série II 318, 87-92.

Carpenter, R.H., Pope, T.A., Smith, R.L., 1975. Fe-Mn oxide coatings in stream sediment geochemical surveys. J. Geochem. Explor. 4, 349-363.

Catts, J.G., Langmuir, D., 1986. Adsorption of $\mathrm{Cu}, \mathrm{Pb}$ and $\mathrm{Zn}$ by (delta) $\mathrm{MnO}_{2}$ : applicability of the site binding-surface complexation model. Appl. Geochem. 1, 255264. 
Cornu, S., Deschatrettes, V., Salvador-Blanes, S., Clozel, B., Hardy, M., Branchut, S., Le Forestier, L., 2005. Trace element accumulation in Mn-Fe-oxide nodules of a planosolic horizon. Geoderma 125, 11-24.

Crowter, D.L., Dillard, J.G., Murray, J.W., 1983. The mechanism of Co(II) oxidation on synthetic birnessite. Geochim. Cosmochim. Acta 47, 1399-1403.

Dillard, J.G., Crowther, D.L., Murray, J.W., 1982. The oxidation states of cobalt and selected metals in Pacific ferromanganese nodules. Geochim. Cosmochim. Acta 46, 755-759.

Evans, L.J., 1989. Chemistry of metal retention by soils. Environ. Sci. Technol. 23, 1046-1056.

Förstner, U. Wittmann, G.T.W., 1979. Metal pollution in the aquatic environment. Springer-Verlag, Berlin.

Gran, G., 1950. Determination of the equivalent point in potentiometric titrations. Acta Chem. Scand. 4, 559-577.

Harter, R.D., 1983. Effect of soil pH on adsorption of lead, copper, zinc, and nickel. Soil Sci. Soc. Am. J. 47, 47-51.

Hem, J.D., Roberson, C.E., Lind, C.J., 1985. Thermodynamic stability of CoOOH and its coprecipitation with manganese. Geochim. Cosmochim. Acta 49, 801-810.

Hem, J.D., Roberson, C.E., Lind, C.J., 1987. Synthesis and stability of hetaerolite, $\mathrm{ZnMn}_{2} \mathrm{O}_{4}$, at $25^{\circ} \mathrm{C}$. Geochim. Cosmochim. Acta 51, 1539-1547.

Hem, J.D., Lind, C.J., Roberson, C.E., 1989. Coprecipitation and redox reactions of manganese oxides with copper and nickel. Geochim. Cosmochim. Acta 53, 2811-2822.

Hem, J.D., Lind, C.J., 1991. Coprecipitation mechanisms and products in manganese oxidation in the presence of cadmium. Geochim. Cosmochim. Acta 55, 2435-2451.

Jenne, E.A., 1968. Controls on $\mathrm{Mn}, \mathrm{Fe}, \mathrm{Co}, \mathrm{Ni}, \mathrm{Cu}$ and $\mathrm{Zn}$ concentration in soils and water: the significant role of hydrous $\mathrm{Mn}$ and Fe oxides. In: Gould, R.F. (Ed.) Trace inorganics in water. Advances in Chemistry of Washington Series 73, 337-387.

Knauer, G.A., Martin, J.H., Gordon, R.M., 1982. Cobalt in north-east Pacific waters. Nature 297, 49-51.

Lienemann, C.-P., Taillefert, M., Perret, D., Gaillard, J.-F., 1997. Association of cobalt and manganese in aquatic systems: chemical and microscopic evidence. Geochim. Cosmochim. Acta 61, 1437-1446.

Lind, C.J., Hem, J.D., 1993. Manganese minerals and associated fine particulates in the streambed of Pinal Creek, Arizona, U.S.A.: a mining-related acid drainage problem. Appl. Geochem. 8, 67-80. 
Manceau, A., Lanson, M., Geoffroy, N., 2007. Natural speciation of Ni, Zn, Ba and As in ferromanganese coatings on quartz using $\mathrm{X}$-ray fluorescence, absorption, and diffraction. Geochim. Cosmochim. Acta 71, 95-128.

McBride, M., Sauvé, S., Hendershot, W., 1997. Solubility control of Cu, Zn, Cd and Pb in contaminated soils. Eur. J. Soil Sci. 48, 337-346.

Means, J.L., Crerar, D.A., Borcsik, M.P., Duguid, J.O., 1978b. Absorption of Co and selected actinides by $\mathrm{Mn}$ and $\mathrm{Fe}$ oxides in soils and sediments. Geochim. Cosmochim. Acta 42, 1763-1773.

Michard, G., 1989. Equilibres chimiques dans les eaux naturelles. Publisud, Paris. Murray, J.W., 1975. The interaction of cobalt with hydrous manganese dioxide. Geochim. Cosmochim. Acta 39, 635-647.

Pelfrêne, A., 2008. Spéciation des métaux traces $(\mathrm{Cd}, \mathrm{Cu}, \mathrm{Pb}, \mathrm{Zn})$ dans les eaux d'un Planosol non pollué (Massif central, France). Thesis Univ. Tours.

Pelfrêne, A., Gassama, N., Grimaud, D., 2008. Dissolved $\mathrm{Cu}(\mathrm{II})$ speciation in unpolluted soil solutions of a planosolic horizon. Electroanalysis 20, 841-850.

Quenardel, J.-M., Rolin, P., 1984. Paleozoic evolution of the Plateau d'Aigurande (NW Massif Central, France). In: Hutton, D.H.W., Sanderson, D.J. (Eds.), Variscan tectonics in the North Atlantic region. Geological Society of London, Spec. Pub., n ${ }^{\circ}$, pp. 6-70.

Ragnarsdottir, K.V., Charlet, L., 2000. Uranium behaviour in natural environments. In: Cotter-Howells, J.D., Campbell, L.S., Valsami-Jones, E., Batchelder, M. (Eds.), Environmental mineralogy: microbial interactions, anthropogenic influences, contaminated land and waste management. The Mineralogy Society Series, 9, Great Britain and Ireland, pp. 245-289.

Robinson, G.D., 1981. Adsorption of $\mathrm{Cu}, \mathrm{Zn}$ and $\mathrm{Pb}$ near sulfide deposits by hydrous manganese-iron oxide coatings on stream alluvium. Chem. Geol. 33, 65-79.

Salvador-Blanes, S., Cornu, S., Hardy, M., Gay-Ovejero, I., Deschatrettes, V., Baize, D., King, D., 2001. Influence des substrats et des formations de versant sur la variabilité spatiale des teneurs naturelles en chrome de sols issus de roches métamorphiques. C. R. Acad. Sci. Paris 332, 681-687.

Salvador-Blanes, S., 2002. Déterminisme de la distribution spatiale des éléments majeurs et traces dans les sols en contexte métamorphique (Plateau d'Aigurande, nord du Massif Central, France). Thesis of University of Tours. 274 p.

Santschi, P.H., 1988. Factors controlling the biogeochemical cycles of trace elements in fresh and coastal marine waters as revealed by artificial radioisotopes. Limnol. Oceanogr. 33, 848-866.

Shaw, T.J., Gieskes, J.M., Jahnke, R.A., 1990. Early diagenesis in differing depositional environments: the response of transition metals in pore water. Geochim. Cosmochim. Acta 54, 1233-1246. 
Sigg, L., Stumm, W., Behra, Ph., 1992. Chimie des milieux aquatiques. Masson, Paris.

Singh, B.R., Steinnes, E., 1994. Soil and water contamination by heavy metals. In: Lal, R., Stewart, B.A. (Eds.) Soil processes and water quality, Boca Raton, London Lewis Publishers, pp. 233-271.

Spencer, D.W., Brewer, P.G., Sachs, P.L., 1972. Aspects of the distribution and trace element composition of suspended matter in the Black Sea. Geochim. Cosmochi. Acta $36,71-86$.

Sposito, G., 1989. Electrochemical phenomena. In: Sposito, G. (Ed.) The chemistry of soils., Oxford University Press., New York, pp. 106-126.

Stumm, W., Morgan, J.J., 1970. Aquatic chemistry: an introduction emphasizing chemical equilibria in natural waters. John Wiley, London.

Stumm, W., Morgan, J.J., 1996. Aquatic chemistry: Chemical equilibria and rates in natural waters. John Wiley, New York.

Thomson, J., Higgs, N.C., Croudace, I.W., Colley, S., Hydes, D.J., 1993. Redox zonation of elements at an oxic / post-oxic boundary in deep-sea sediments. Geochim. Cosmochim. Acta 57, 579-595. 


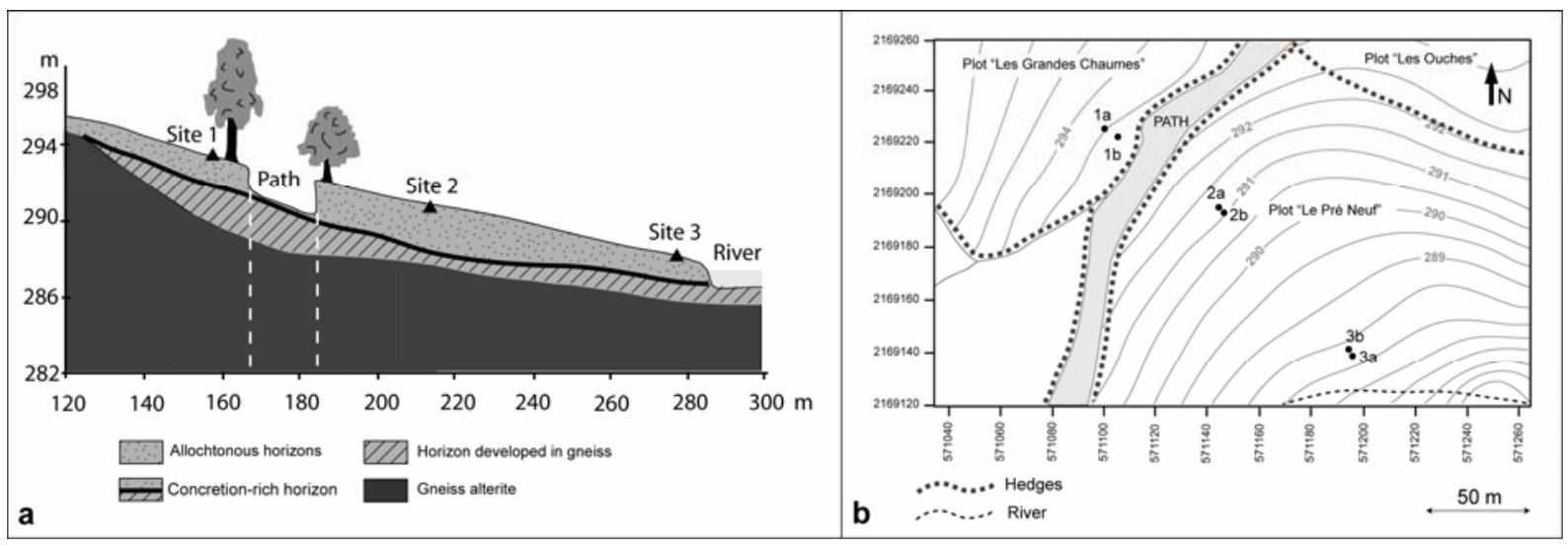

Figure 1 a) Schematic diagram of the studied toposequence (modified from Cornu et al., 2005). b) Study area and location of three water sampling sites (piezometers 1a, 1b, 2a, 2b, 3a and 3b) (modified from Alberic et al., Unpublished study).
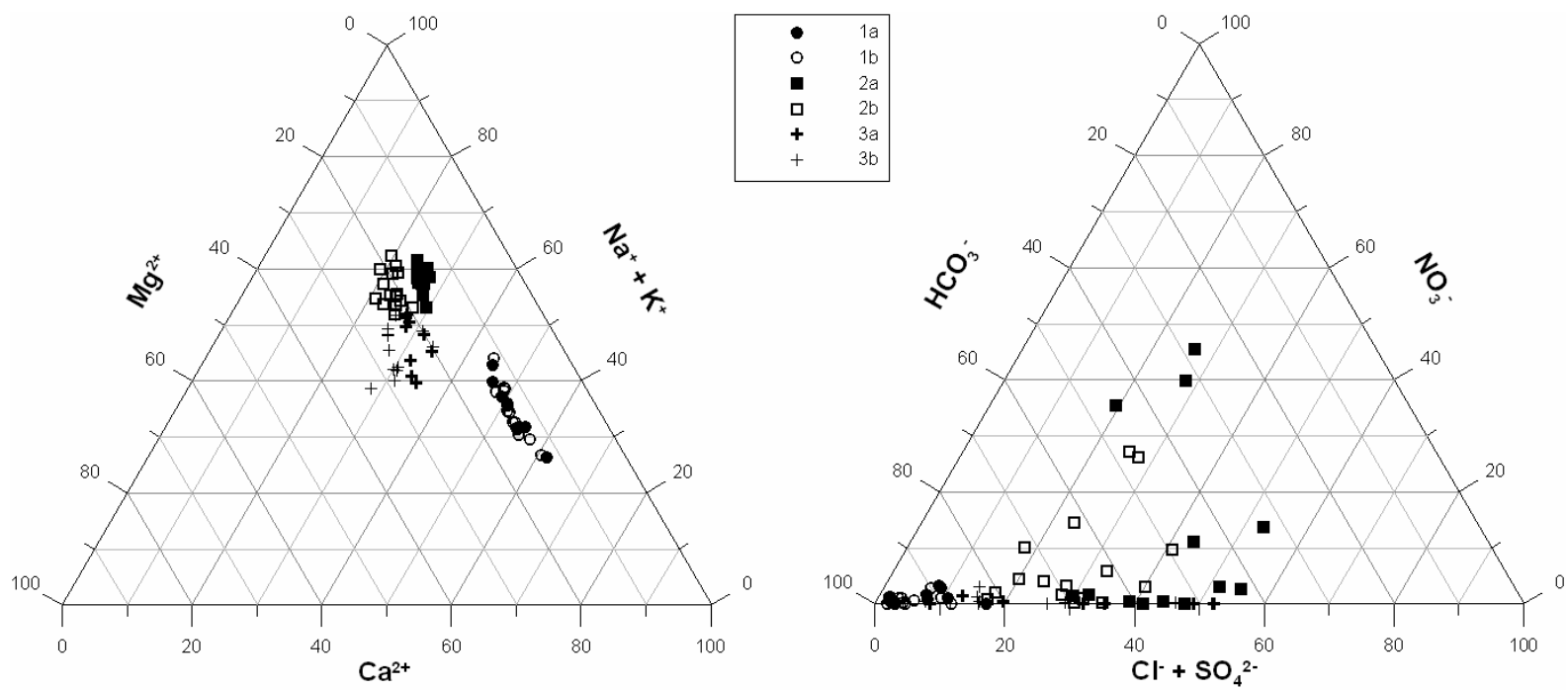

Figure 2: Cation and anion distribution (expressed in $\% \mathrm{~mol} / \mathrm{L}$ ) in the three soil solution sites from 2004 to 2006 . 


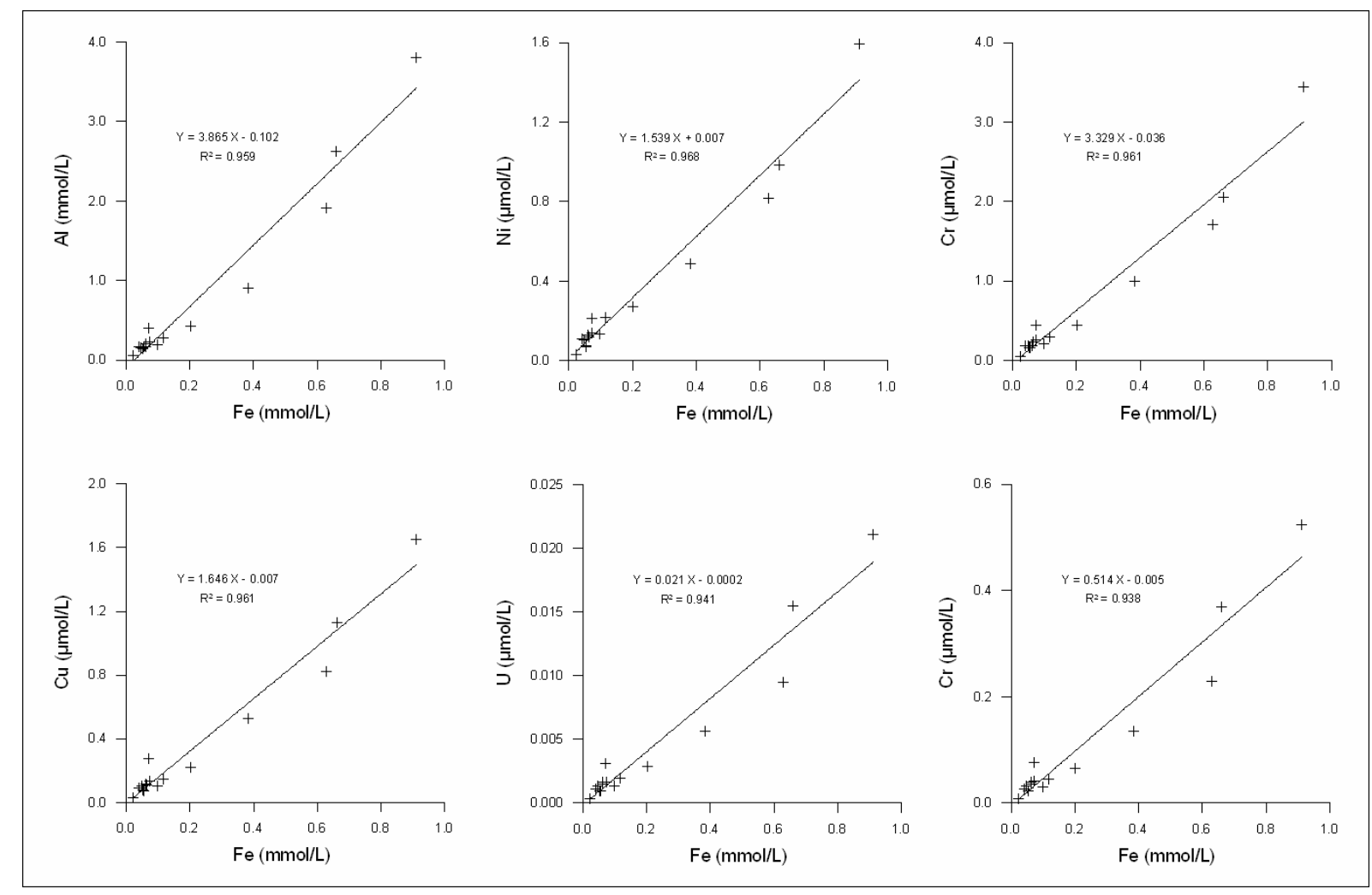

Figure 3: Correlations between some trace elements and $\mathrm{Fe}$ in $2 \mathrm{~b}$, the particulate phase of soil solutions.

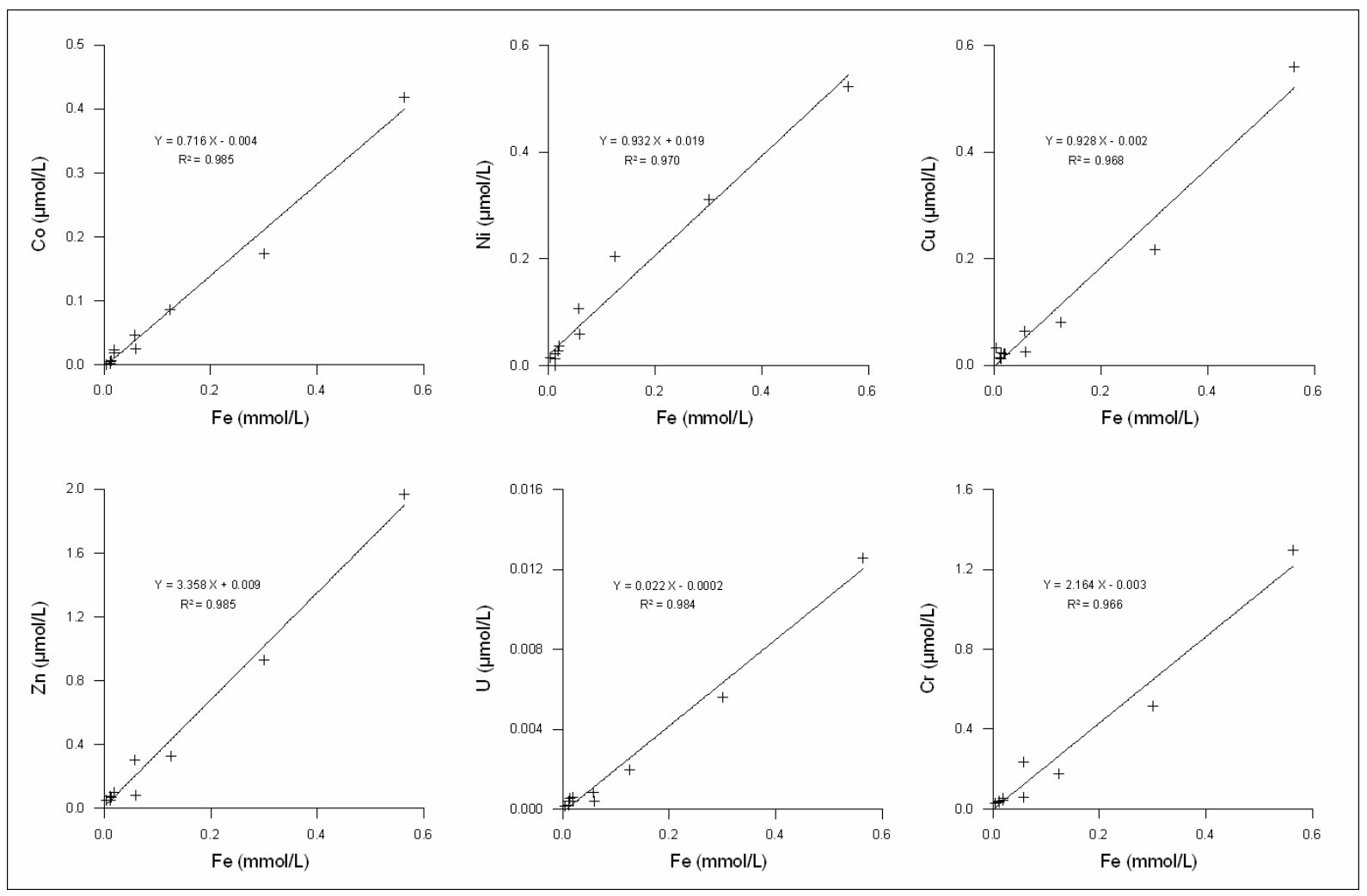

Figure 4: Correlations between some trace metals and $\mathrm{Fe}$ in $3 \mathrm{~b}$, the particulate phase of soil solutions. 


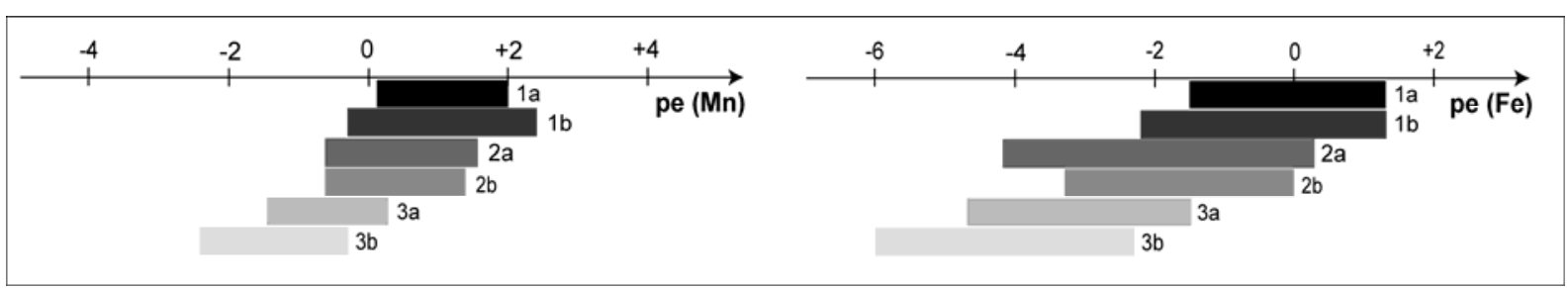

Figure 5: $\mathrm{pE}$ range calculated for the soil solutions from the six piezometers (see text for explanation).

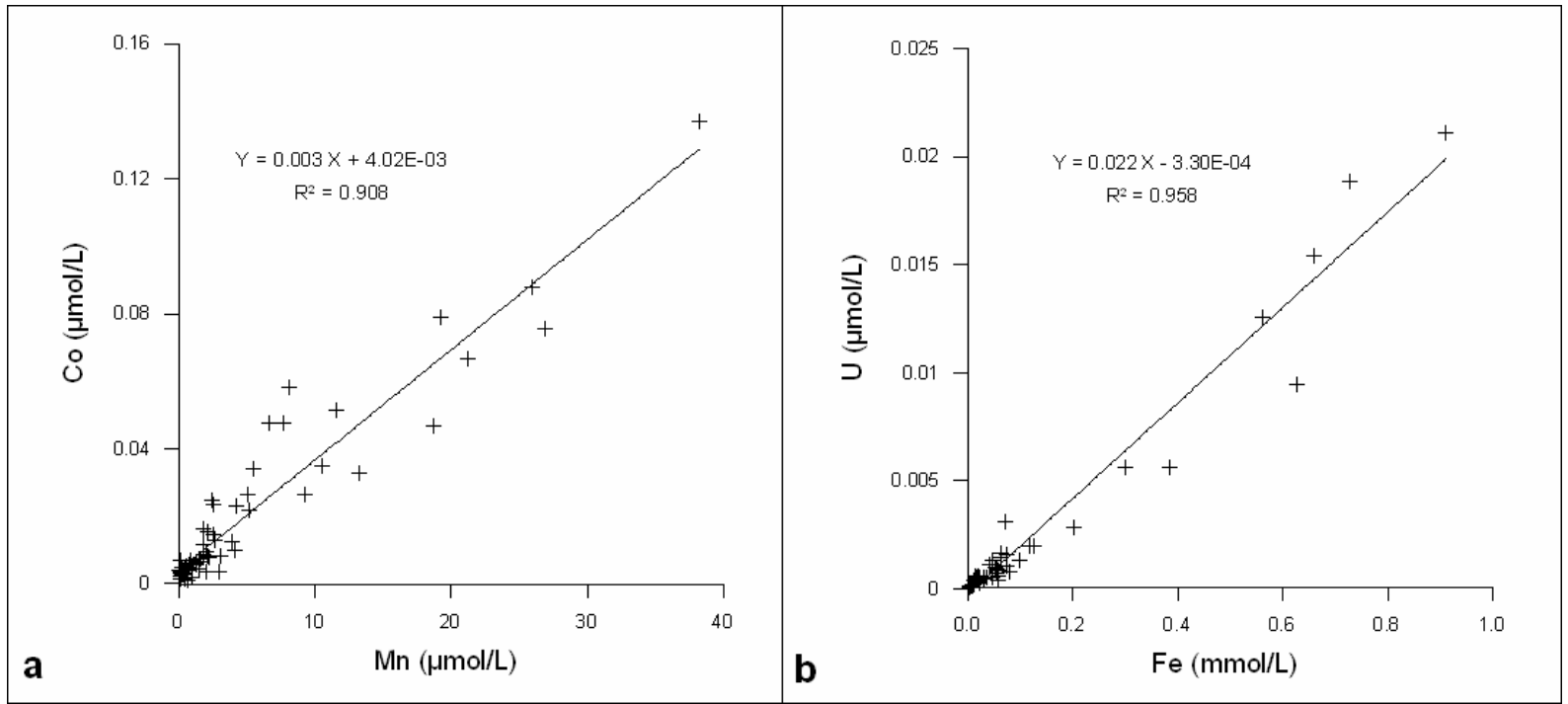

Figure 6: a) Correlations between Co and $\mathrm{Mn}$ in the soluble phase (piezometers 1a, 1b, 2a, 2b, $3 a$ and $3 b$ ). b) Correlations between $U$ and $F e$ in the particulate phase (piezometers $1 b, 2 a, 2 b$ and $3 b)$. 
Table 1: Analytical results (mean, min, max and median) for samples from 1a, 1b, 2a, $2 \mathrm{~b}, 3 \mathrm{a}$ and $3 \mathrm{~b}$ in the dissolved phase.

\begin{tabular}{|c|c|c|c|c|c|c|c|c|c|c|c|c|c|c|c|}
\hline & & $\mathrm{T}^{\circ} \mathrm{C}$ & $\mathrm{pH}$ & $\mathrm{C}$ & $\mathrm{HCO}_{3}^{-}$ & $\mathrm{Na}^{+}$ & $\mathrm{K}^{+}$ & $\mathrm{Ca}^{2+}$ & $\mathrm{Mg}^{2+}$ & $\mathrm{H}_{4} \mathrm{SiO}_{4}$ & $\mathrm{Cl}^{-}$ & $\mathrm{SO}_{4}{ }^{2-}$ & $\mathrm{NO}_{3}^{-}$ & $\sum \mathrm{PO}_{4}$ & $\mathrm{~F}^{-}$ \\
\hline & & & & $\mu \mathrm{S} / \mathrm{cm}$ & $\mathrm{mM}$ & $\mathrm{mM}$ & $\mu \mathrm{M}$ & $\mathrm{mM}$ & $\mu \mathrm{M}$ & $\mathrm{mM}$ & $\mu \mathrm{M}$ & $\mu \mathrm{M}$ & $\mu \mathrm{M}$ & $\mu \mathrm{M}$ & $\mu \mathrm{M}$ \\
\hline \multirow{3}{*}{$1 a$} & Mean & 9.0 & 6.25 & 79 & 0.71 & 0.15 & 7.03 & 0.24 & 62.1 & 0.18 & 29.0 & 22.0 & 14.4 & 0.65 & 7.0 \\
\hline & Min - Max & $3.1-14.3$ & $5.57-6.60$ & $62-100$ & $0.41-1.03$ & $0.12-0.18$ & $2.20-12.50$ & $0.16-0.33$ & $42.8-86.8$ & $0.16-0.22$ & $8.8-65.6$ & 3.5 - 38.2 & $1.5-32.0$ & $0.28-0.87$ & $5.2-8$. \\
\hline & Median & 9.5 & 6.32 & 81 & 0.79 & 0.15 & 6.61 & 0.23 & 63.5 & 0.17 & 15.6 & 26.5 & 11.6 & 0.70 & 7.2 \\
\hline \multirow{3}{*}{$1 b$} & Mean & 7.2 & 5.93 & 85 & 0.81 & 0.16 & 4.54 & 0.26 & 67.1 & 0.19 & 22.9 & 18.2 & 9.8 & 0.59 & 5.9 \\
\hline & Min - Max & $1.6-13.5$ & $5.56-6.62$ & $54-106$ & $0.46-1.13$ & $0.14-0.20$ & $2.64-8.09$ & $0.15-0.37$ & 38.5 - 89.5 & $0.15-0.26$ & $8.3-65.1$ & $4.3-41.0$ & $0.0-32.0$ & $0.34-0.70$ & $3.7-7$. \\
\hline & Median & 7,0 & 5.85 & 87 & 0.86 & 0.16 & 4.17 & 0.28 & 67.9 & 0.18 & 11.9 & 15.0 & 10.1 & 0.61 & 6.1 \\
\hline \multirow{3}{*}{$2 a$} & Mean & 9.1 & 6.60 & 289 & 1.10 & 0.99 & 1.12 & 0.45 & 267.7 & 0.17 & 621.5 & 275.4 & 260.5 & 0.55 & 5.4 \\
\hline & Min - Max & $1.8-14.0$ & $5.91-7.25$ & $217-525$ & $0.60-1.70$ & $0.91-1.17$ & $0.00-3.14$ & $0.40-0.56$ & $211.0-321.0$ & $0.14-0.27$ & $222.3-972.3$ & $205.7-309.0$ & $0.9-970.0$ & $0.43-0.65$ & $3.5-7$. \\
\hline & Median & 9.1 & 6.66 & 265 & 1.09 & 0.99 & 0.78 & 0.43 & 258.5 & 0.18 & 748.0 & 274.0 & 55.1 & 0.57 & 5.3 \\
\hline \multirow{3}{*}{$2 b$} & Mean & 9.8 & 6.55 & 248 & 1.52 & 0.94 & 7.46 & 0.38 & 352.2 & 0.33 & 376.1 & 228.9 & 129.6 & 0.47 & 11.5 \\
\hline & Min - Max & $3.7-15.3$ & $6.09-7.08$ & $106-295$ & $0.81-2.11$ & $0.79-1.09$ & $0.59-43.30$ & $0.25-0.50$ & $259.8-456.0$ & $0.22-0.54$ & $97.4-614.0$ & $170.0-321.0$ & $5.6-500.0$ & $0.00-0.71$ & $7.6-18$ \\
\hline & Median & 9.4 & 6.59 & 260 & 1.60 & 0.93 & 2.89 & 0.38 & 346.5 & 0.31 & 425.5 & 226.5 & 72.5 & 0.52 & 10.5 \\
\hline \multirow{3}{*}{$3 a$} & Mean & 7.7 & 6.76 & 295 & 2.19 & 0.89 & 38.82 & 0.61 & 447.0 & 0.14 & 351.0 & 253.5 & 10.6 & 0.51 & 10.0 \\
\hline & Min - Max & $1.2-15.5$ & $6.25-7.40$ & $185-372$ & $1.13-3.88$ & $0.61-1.02$ & $3.90-90.30$ & $0.46-0.86$ & $274.0-657.0$ & $0.10-0.21$ & $34.0-686.0$ & $37.0-553.0$ & $0.0-29.0$ & $0.00-0.85$ & $8.0-12$ \\
\hline & Median & 6.8 & 6.86 & 306 & 1.75 & 0.92 & 30.57 & 0.51 & 390.9 & 0.12 & 471.0 & 169.0 & 3.4 & 0.55 & 9.7 \\
\hline \multirow{3}{*}{$3 b$} & Mean & 10.1 & 7.04 & 322 & 2.60 & 0.96 & 17.37 & 0.62 & 570.1 & 0.24 & 325.0 & 222.7 & 21.0 & 0.44 & 16.8 \\
\hline & Min - Max & $3.3-20.0$ & $6.69-7.54$ & $188-446$ & $1.15-3.92$ & $0.64-1.19$ & $3.10-58.40$ & $0.46-0.91$ & $278.0-938.0$ & $0.13-0.67$ & $61.0-696.0$ & $56.1-548.0$ & $0.0-148.7$ & $0.00-0.60$ & $10.7-25$ \\
\hline & Median & 9.1 & 7,00 & 308 & 2.40 & 0.94 & 12.80 & 0.52 & 512.6 & 0.21 & 260.4 & 182.0 & 5.7 & 0.48 & 16.3 \\
\hline
\end{tabular}


Table 2: Concentrations of $\mathrm{HCO}_{3}{ }^{-}, \mathrm{Cl}^{-}, \mathrm{SO}_{4}{ }^{2-}, \mathrm{NO}_{3}{ }^{-}, \mathrm{Mn}$ and $\mathrm{Fe}$ in the dissolved fraction for each year.

\begin{tabular}{|c|c|c|c|c|c|c|c|}
\hline & & $\begin{array}{c}\mathrm{HCO}_{3}{ }^{-} \\
\mathrm{mM}\end{array}$ & $\begin{array}{l}\mathrm{Cl}^{-} \\
\mu \mathrm{M}\end{array}$ & $\begin{array}{c}\mathrm{SO}_{4}{ }^{2-} \\
\mu \mathrm{M}\end{array}$ & $\begin{array}{c}\mathrm{NO}_{3}{ }^{-} \\
\mu \mathrm{M}\end{array}$ & $\begin{array}{l}\mathrm{Mn} \\
\mu \mathrm{M}\end{array}$ & $\begin{array}{l}\mathrm{Fe} \\
\mu \mathrm{M}\end{array}$ \\
\hline \multirow{3}{*}{$2 a$} & 2004 & $1.33 \pm 0.18$ & $332.5 \pm 38.5$ & $269.5 \pm 7.5$ & $30.0 \pm 1.1$ & $0.09 \pm 0.06$ & $0.14 \pm 0.04$ \\
\hline & 2004-2005 & $1.35 \pm 0.36$ & $597.3 \pm 375.0$ & $256.4 \pm 50.7$ & $395.4 \pm 381.2$ & $0.96 \pm 0.88$ & $1.41 \pm 0.98$ \\
\hline & $2005-2006$ & $0.96 \pm 0.36$ & $607.0 \pm 349.0$ & $289.5 \pm 19.5$ & $485.4 \pm 484.6$ & $1.08 \pm 1.02$ & $1.59 \pm 1.25$ \\
\hline \multirow{3}{*}{$2 b$} & 2004 & $1.59 \pm 0.26$ & $414.5 \pm 105.5$ & $181.0 \pm 11.0$ & $75.0 \pm 51.0$ & $9.60 \pm 9.59$ & $1.25 \pm 1.15$ \\
\hline & 2004-2005 & $1.84 \pm 0.27$ & $361.7 \pm 252.3$ & $229.7 \pm 36.7$ & $121.2 \pm 101.6$ & $2.65 \pm 2.50$ & $1.32 \pm 0.96$ \\
\hline & 2005 & $1.42 \pm 0.60$ & $340.7 \pm 243.3$ & $248.5 \pm 72.5$ & $252.8 \pm 247.2$ & $4.69 \pm 4.59$ & $0.97 \pm 0.46$ \\
\hline \multirow{3}{*}{$3 a$} & 2004 & $1.76 \pm 0.01$ & $77.5 \pm 17.5$ & $136.0 \pm 33.0$ & $14.5 \pm 14.5$ & $0.81 \pm 0.47$ & $1.10 \pm 1.00$ \\
\hline & 2004-2005 & $3.48 \pm 0.41$ & $323.6 \pm 289.6$ & $85.4 \pm 48.4$ & $19.1 \pm 0.4$ & $14.62 \pm 4.09$ & $7.02 \pm 1.78$ \\
\hline & $2005-2006$ & $1.43 \pm 0.30$ & $578.5 \pm 107.5$ & $436.0 \pm 117.0$ & $2.4 \pm 1.0$ & $0.87 \pm 0.68$ & $1.77 \pm 0.49$ \\
\hline \multirow{3}{*}{$3 b$} & 2004 & $1.75 \pm 0.05$ & $93.0 \pm 32.0$ & $144.5 \pm 37.5$ & $14.0 \pm 14.0$ & $1.16 \pm 1.01$ & $1.29 \pm 1.19$ \\
\hline & $2004-2005$ & $3.70 \pm 0.23$ & $337.4 \pm 239.4$ & $122.8 \pm 66.7$ & $83.7 \pm 65.1$ & $29.71 \pm 8.47$ & $21.60 \pm 21.50$ \\
\hline & $2005-2006$ & $1.90 \pm 0.75$ & $439.7 \pm 256.3$ & $356.1 \pm 191.9$ & $2.9 \pm 2.9$ & $6.68 \pm 4.92$ & $2.89 \pm 1.58$ \\
\hline
\end{tabular}


Table 3: Concentrations of $\mathrm{Al}, \mathrm{Mn}, \mathrm{Fe}, \mathrm{Si}$ and organic matter in the dissolved and particulate fraction for each piezometer (expressed as mol/L of solution).

\begin{tabular}{|c|c|c|c|c|c|c|c|c|c|c|c|c|c|c|c|c|}
\hline & & $\begin{array}{c}\text { Al diss } \\
\mu \mathrm{M}\end{array}$ & $\begin{array}{c}\text { Al part } \\
\mu \mathrm{M}\end{array}$ & $\begin{array}{c}\text { Al part } \\
\%\end{array}$ & $\begin{array}{c}\text { Mn diss } \\
\mu \mathrm{M}\end{array}$ & $\begin{array}{c}\text { Mn part } \\
\mu \mathrm{M}\end{array}$ & $\begin{array}{c}\text { Mn part } \\
\%\end{array}$ & $\begin{array}{c}\text { Fe diss } \\
\mu \mathrm{M}\end{array}$ & $\begin{array}{c}\text { Fe part } \\
\mu \mathrm{M}\end{array}$ & $\begin{array}{c}\text { Fe part } \\
\%\end{array}$ & $\begin{array}{c}\text { Si diss } \\
\mathrm{mM}\end{array}$ & $\begin{array}{c}\text { Si part } \\
\mathrm{mM}\end{array}$ & $\begin{array}{c}\text { Si part } \\
\%\end{array}$ & $\begin{array}{l}\mathrm{DOC} \\
\mathrm{mg} / \mathrm{L}\end{array}$ & $\begin{array}{l}\mathrm{POC} \\
\mathrm{mg} / \mathrm{L}\end{array}$ & $\begin{array}{c}\mathrm{POC} \\
\% \\
\end{array}$ \\
\hline \multirow{4}{*}{$1 a$} & mean & 2.74 & 184.3 & 88.3 & 1.28 & 2.05 & 48.1 & 2.17 & 90.2 & 75.6 & 0.18 & 0.32 & 55.6 & 11.2 & 1.4 & 13.2 \\
\hline & $\min$ & 0.28 & 5.6 & 62.5 & 0.08 & 0.08 & 6.5 & 0.10 & 1.53 & 37.4 & 0.16 & 0.03 & 12.5 & 4.9 & 0.0 & 0.0 \\
\hline & $\max$ & 9.99 & 693.8 & 100.0 & 2.60 & 8.74 & 97.8 & 5.20 & 341.0 & 99.9 & 0.22 & 0.60 & 77.0 & 17.5 & 6.1 & 55.8 \\
\hline & median & 1.76 & 26.5 & 95.3 & 1.24 & 0.48 & 49.2 & 2.39 & 7.34 & 78.6 & 0.17 & 0.36 & 68.5 & 10.9 & 0.6 & 3.6 \\
\hline \multirow{4}{*}{ 1b } & mean & 1.59 & 149.8 & 95.6 & 3.19 & 2.21 & 34.7 & 1.59 & 159.4 & 87.6 & 0.19 & 0.37 & 58.1 & 10.8 & 1.6 & 14 \\
\hline & $\min$ & 0.27 & 13.9 & 83.7 & 0.25 & 0.06 & 1.6 & 0.10 & 2.26 & 61.5 & 0.15 & 0.00 & 0.0 & 4.7 & 0.0 & 0.0 \\
\hline & $\max$ & 4.89 & 769.1 & 100.0 & 8.10 & 11.00 & 76.5 & 2.82 & 1010.0 & 99.9 & 0.26 & 0.73 & 80.5 & 21.8 & 4.4 & 44. \\
\hline & median & 1.06 & 74.3 & 98.5 & 2.42 & 1.80 & 36.5 & 1.40 & 29.71 & 95.4 & 0.18 & 0.41 & 68.8 & 10.5 & 1.6 & 14.0 \\
\hline \multirow{4}{*}{$2 a$} & mean & 1.89 & 101.5 & 95.7 & 0.53 & 0.77 & 61.0 & 1.18 & 39.81 & 93.3 & 0.17 & 0.24 & 41.1 & 9.8 & 3.2 & 22.6 \\
\hline & $\min$ & 0.10 & 25.4 & 82.9 & 0.03 & 0.00 & 0.0 & 0.10 & 8.27 & 75.2 & 0.14 & 0.00 & 0.0 & 4.3 & 0.0 & 0.0 \\
\hline & $\max$ & 5.85 & 305.7 & 99.9 & 2.10 & 1.97 & 98.2 & 2.84 & 130.0 & 99.9 & 0.22 & 0.66 & 81.7 & 18.3 & 10.5 & 50. \\
\hline & median & 1.09 & 77.3 & 98.4 & 0.12 & 0.52 & 72.8 & 1.18 & 29.8 & 96.2 & 0.18 & 0.10 & 38.4 & 8.5 & 2.5 & \\
\hline \multirow{4}{*}{$2 b$} & mean & 0.96 & 1033.8 & 99.7 & 2.98 & 5.73 & 61.8 & 1.06 & 466.7 & 99.0 & 0.33 & 0.62 & 50.1 & 12.7 & 10.0 & 38 \\
\hline & $\min$ & 0.10 & 61.7 & 99.3 & 0.01 & 0.20 & 4.8 & 0.10 & 22.68 & 96.5 & 0.22 & 0.01 & 3.7 & 5.4 & 0.0 & 0.0 \\
\hline & $\max$ & 2.88 & 3999.0 & 100.0 & 19.20 & 31.10 & 99.9 & 2.40 & 4185.0 & 100.0 & 0.54 & 2.45 & 90.8 & 27.2 & 41.0 & 75. \\
\hline & median & 0.89 & 258.1 & 99.7 & 1.22 & 2.25 & 65.9 & 0.97 & 85.74 & 99.1 & 0.31 & 0.36 & 47.2 & 11.9 & 8.6 & 0 \\
\hline \multirow{4}{*}{$3 a$} & mean & 2.18 & 435.9 & 97.3 & 5.21 & 2.78 & 54.0 & 3.21 & 103.77 & 91.6 & 0.14 & 0.17 & 43.3 & 21.4 & 2.5 & \\
\hline & $\min$ & 1.31 & 32.3 & 94.5 & 0.18 & 0.55 & 4.0 & 0.10 & 13.82 & 76.4 & 0.10 & 0.01 & 2.6 & 15.8 & 0.0 & 0.0 \\
\hline & $\max$ & 3.64 & 3199.0 & 99.9 & 18.70 & 10.18 & 96.8 & 8.80 & 620.0 & 99.9 & 0.21 & 0.40 & 79.8 & 33.5 & 8.7 & 35. \\
\hline & median & 1.81 & 73.4 & 97.7 & 1.28 & 2.31 & 67.1 & 2.09 & 38.36 & 91.8 & 0.12 & 0.14 & 40.2 & 19.9 & 2.0 & 10 \\
\hline \multirow{4}{*}{$3 b$} & mean & 1.53 & 719.5 & 97.7 & 14.32 & 8.39 & 26.0 & 6.06 & 974.9 & 88.4 & 0.24 & 0.28 & 51.5 & 18.3 & 3.6 & 14.1 \\
\hline & $\min$ & 0.26 & 29.1 & 91.8 & 0.15 & 0.00 & 0.0 & 0.10 & 3.85 & 46.3 & 0.13 & 0.00 & 0.0 & 11.4 & 0.0 & 0.0 \\
\hline & $\max$ & 3.60 & 6466.4 & 99.9 & 38.18 & 64.88 & 97.6 & 43.10 & 11165.0 & 99.9 & 0.67 & 0.53 & 74.1 & 26.2 & 18.6 & 54. \\
\hline & median & 1.07 & 64.0 & 99.2 & 7.63 & 2.31 & 16.5 & 2.25 & 57.52 & 90.0 & 0.21 & 0.25 & 57.3 & 17.0 & 1.6 & 8.2 \\
\hline
\end{tabular}


Table 4: Concentrations of $\mathrm{Cd}, \mathrm{Co}, \mathrm{Cu}, \mathrm{Cr}, \mathrm{Ni}, \mathrm{Pb}, \mathrm{Zn}$ and $\mathrm{U}$ in the dissolved and particulate fraction for each piezometer (express as mol/L of solution).

\begin{tabular}{|c|c|c|c|c|c|c|c|c|c|c|c|c|c|c|c|c|c|c|c|}
\hline & & $\begin{array}{c}\begin{array}{c}\text { Cd diss } \\
\mathrm{nM}\end{array} \\
\end{array}$ & $\begin{array}{c}\text { Cd part } \\
\mathrm{nM}\end{array}$ & $\begin{array}{c}\text { Cd part } \\
\%\end{array}$ & $\begin{array}{c}\text { Co diss } \\
\mathrm{nM}\end{array}$ & $\begin{array}{c}\text { Co part } \\
\mathrm{nM}\end{array}$ & $\begin{array}{c}\text { Co part } \\
\%\end{array}$ & $\begin{array}{c}\text { Cu diss } \\
\mathrm{nM}\end{array}$ & $\begin{array}{c}\text { Cu part } \\
n M\end{array}$ & $\begin{array}{c}\text { Cu part } \\
\%\end{array}$ & $\begin{array}{c}\text { Cr diss } \\
\mathrm{nM}\end{array}$ & $\begin{array}{c}\text { Cr part } \\
\mathrm{nM}\end{array}$ & $\begin{array}{c}\text { Cr part } \\
\%\end{array}$ & $\begin{array}{c}\text { Ni diss } \\
\mathrm{nM}\end{array}$ & $\begin{array}{c}\text { Ni part } \\
\mathrm{nM}\end{array}$ & $\begin{array}{c}\text { Ni part } \\
\%\end{array}$ & $\begin{array}{c}\mathrm{Pb} \text { diss } \\
\mathrm{nM}\end{array}$ & $\begin{array}{c}\text { Pb part } \\
\mathrm{nM}\end{array}$ & $\mathrm{Pb}$ \\
\hline \multirow{4}{*}{$1 a$} & mean & 0.74 & 1.15 & 60.8 & 6.61 & 51.8 & 88.7 & 52.4 & 78.1 & 59.8 & 6.3 & 165,0 & 96.3 & 22.3 & 93.3 & 80.7 & 0.81 & 24.95 & 9 \\
\hline & $\min$ & 0.25 & 0.02 & 7.4 & 1.43 & 2.4 & 62.7 & 37.7 & 0.5 & 1.3 & 2.9 & 6.4 & 68.8 & 16.3 & 1.2 & 6.8 & 0.09 & 1.31 & \\
\hline & $\max$ & 1.34 & 3.5 & 72.3 & 14.61 & 204.3 & 93.3 & 77.3 & 285.7 & 78.7 & 14.9 & 549.3 & 97.4 & 32.5 & 277.1 & 89.5 & 2.3 & 101.58 & \\
\hline & median & 0.72 & 0.62 & 46.3 & 4.92 & 9.1 & 64.9 & 52.1 & 19.5 & 27.2 & 5,0 & 29.2 & 85.4 & 21.8 & 21.4 & 49.5 & 0.62 & 4.82 & \\
\hline \multirow{4}{*}{$1 b$} & mean & 0.57 & 1.15 & 66.9 & 16.97 & 60.6 & 78.1 & 39.3 & 78.5 & 66.6 & 4.2 & 162.8 & 97.5 & 25.7 & 84,0 & 76.6 & 0.5 & 24.26 & \\
\hline & $\min$ & 0,00 & 0.04 & 100.0 & 2.55 & 4.2 & 62.2 & 24.9 & 11.3 & 31.2 & 2.6 & 14.3 & 84.6 & 6.6 & 7.5 & 53.2 & 0.05 & 2.33 & \\
\hline & $\max$ & 1.05 & 4.1 & 79.6 & 58.33 & 324.3 & 84.7 & 56.4 & 356.3 & 86.3 & 9.1 & 826.2 & 98.9 & 86.7 & 409,0 & 82.5 & 1.22 & 117.08 & \\
\hline & median & 0.54 & 0.52 & 49.1 & 11.74 & 29.2 & 71.3 & 39,0 & 45.7 & 53.9 & 4.1 & 89.1 & 95.6 & 22.2 & 41,0 & 64.9 & 0.43 & 14.6 & \\
\hline \multirow{4}{*}{$2 a$} & mean & 0.67 & 0.79 & 54.1 & 4.16 & 34.5 & 89.2 & 30.4 & 51.9 & 63.1 & 5.9 & 93.1 & 94.0 & 12.2 & 72,0 & 85.5 & 0.36 & 14.27 & \\
\hline & $\min$ & 0.25 & 0,00 & 0.0 & 1.56 & 8.7 & 84.8 & 21.2 & 11.4 & 34.9 & 3.3 & 23.9 & 87.9 & 7.9 & 9.3 & 54.1 & 0.02 & 3.84 & \\
\hline & $\max$ & 1.35 & 5.31 & 79.7 & 8.49 & 88,0 & 91.2 & 37.2 & 122.3 & 76.7 & 9.5 & 231.4 & 96.1 & 19.3 & 234.7 & 92.4 & 0.96 & 29.15 & 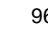 \\
\hline & median & 0.65 & 0.52 & 44.4 & 3.39 & 27.5 & 89.0 & 28.9 & 46.3 & 61.6 & 5.4 & 76,0 & 93.4 & 10.8 & 60.8 & 84.9 & 0.26 & 11.64 & 0 \\
\hline \multirow{4}{*}{$2 b$} & mean & 0.86 & 5.38 & 86.2 & 11.33 & 316.5 & 96.5 & 29.5 & 464.5 & 94.0 & 3.8 & 962,0 & 99.6 & 13.2 & 452.3 & 97.2 & 0.46 & 138.73 & \\
\hline & $\min$ & 0,00 & 0.09 & 100.0 & 0.96 & 17.5 & 94.8 & 11.2 & 26.8 & 70.5 & 1.8 & 55.4 & 96.8 & 6.9 & 30.9 & 81.7 & 0.02 & 8.44 & \\
\hline & $\max$ & 2.35 & 34.95 & 93.7 & 78.88 & 1220.6 & 93.9 & 101.9 & 1654,0 & 94.2 & 5.9 & 3881.8 & 99.8 & 33.2 & 1719.1 & 98.1 & 1.71 & 524.81 & \\
\hline & median & 0.54 & 0.99 & 64.7 & 4.94 & 96.4 & 95.1 & 23.4 & 141.2 & 85.8 & 3.4 & 281.1 & 98.8 & 11.2 & 176.3 & 94.0 & 0.25 & 43.52 & \\
\hline \multirow{4}{*}{$3 a$} & mean & 0.63 & 1.39 & 68.8 & 16.47 & 55.8 & 77.2 & 52.7 & 70.1 & 57.1 & 16.8 & 288.1 & 94.5 & 45.1 & 113.7 & 71.6 & 1.14 & 43.85 & \\
\hline & $\min$ & 0.25 & 0.17 & 40.5 & 4.07 & 11.4 & 73.7 & 26.6 & 0,0 & 0.0 & 12.9 & 28.2 & 68.6 & 21.6 & 0,0 & 0.0 & 0.49 & 7.96 & \\
\hline & $\max$ & 1.28 & 5.65 & 81.5 & 46.99 & 242.2 & 83.8 & 74,0 & 386.4 & 83.9 & 22.4 & 1951.2 & 98.9 & 110.3 & 513.2 & 82.3 & 3.76 & 206.54 & \\
\hline & median & 0.47 & 0.71 & 60.2 & 7.17 & 26.6 & 78.8 & 54,0 & 25.7 & 32.2 & 16.1 & 66.4 & 80.5 & 35,0 & 63.2 & 64.3 & 0.95 & 17.41 & \\
\hline \multirow{4}{*}{$3 b$} & mean & 0.38 & 2.31 & 85.9 & 48.2 & 180.6 & 78.9 & 32.4 & 226.4 & 87.5 & 11.4 & 561.2 & 98.0 & 40.5 & 269.4 & 86.9 & 0.71 & 107.41 & \\
\hline & $\min$ & 0,00 & 0.26 & 100.0 & 2.77 & 0,0 & 0.0 & 14,0 & 12.1 & 46.4 & 6.5 & 30.8 & 82.6 & 25,0 & 0,0 & 0.0 & 0.12 & 5.31 & 9 \\
\hline & $\max$ & 1.06 & 15.47 & 93.6 & 136.9 & 1487,0 & 91.6 & 64.9 & 1805.2 & 96.5 & 18.4 & 4598.9 & 99.6 & 63.5 & 2105,0 & 97.1 & 1.7 & 710.23 & \\
\hline & median & 0.31 & 0.79 & 71.8 & 47.72 & 24.7 & 34.1 & 31.8 & 33.3 & 51.2 & 10,0 & 59.4 & 85.6 & 37.4 & 58.7 & 61.1 & 0.68 & 13.35 & \\
\hline \multirow{5}{*}{$1 a$} & & $\begin{array}{c}\text { Zn diss } \\
\mathrm{nM}\end{array}$ & $\begin{array}{c}\text { Zn part } \\
n M\end{array}$ & $\begin{array}{c}\text { Zn part } \\
\%\end{array}$ & $\begin{array}{c}\mathrm{U} \text { diss } \\
\mathrm{nM}\end{array}$ & $\begin{array}{c}U \text { p part } \\
n M\end{array}$ & $\begin{array}{c}\text { U part } \\
\%\end{array}$ & $\begin{array}{c}\text { Ba diss } \\
\mathrm{nM}\end{array}$ & $\begin{array}{c}\text { Ba part } \\
n M\end{array}$ & $\begin{array}{c}\text { Ba part } \\
\%\end{array}$ & $\mathrm{Rb}$ diss & Rb part & Rb part & $\begin{array}{c}\text { Sr diss } \\
\mathrm{mM}\end{array}$ & Sr part & Sr part & & & \\
\hline & mean & 64.9 & 324.7 & 83.3 & 0.09 & 0.89 & 90.8 & 110.4 & 234.1 & 68.0 & 8.7 & 114.5 & 92.9 & 0.31 & 40.79 & 99.2 & & & \\
\hline & $\min$ & 20.8 & 0,0 & 0.0 & 0.05 & 0.03 & 37.5 & 83.2 & 7.5 & 8.3 & 4.4 & 3.7 & 45.5 & 0.21 & 4.13 & 95.1 & & & \\
\hline & $\max$ & 171.4 & 1138.1 & 86.9 & 0.16 & 3.37 & 95.5 & 158.5 & 785.1 & 83.2 & 12.9 & 387.3 & 96.8 & 0.45 & 129.25 & 99.7 & & & \\
\hline & median & 51.5 & 79.7 & 60.7 & 0.08 & 0.16 & 66.7 & 111.9 & 49.2 & 30.5 & 9.3 & 20.9 & 69.2 & 0.33 & 15.81 & 98.0 & & & \\
\hline \multirow{4}{*}{$1 b$} & mean & 40.3 & 339.9 & 89.4 & 0.07 & 0.83 & 92.2 & 91.9 & 269.0 & 74.5 & 5.8 & 117.0 & 95.2 & 0.34 & 37.28 & 99.1 & & & \\
\hline & $\min$ & 4.3 & 41.9 & 90.7 & 0.05 & 0.09 & 64.3 & 65.6 & 24.7 & 27.4 & 3.7 & 10.5 & 74.2 & 0.20 & 3.50 & 94.5 & & & \\
\hline & $\max$ & 76.3 & 1615,0 & 95.5 & 0.09 & 4.06 & 97.8 & 117.7 & 1329.9 & 91.9 & 9.6 & 580.4 & 98.4 & 0.49 & 142.88 & 99.7 & & & \\
\hline & median & 46.4 & 194.9 & 80.8 & 0.06 & 0.5 & 89.3 & 95.6 & 140.6 & 59.5 & 5.6 & 62.3 & 91.7 & 0.35 & 20.23 & 98.3 & & & \\
\hline \multirow{4}{*}{$2 a$} & mean & 46.2 & 209.6 & 81.9 & 0.06 & 0.63 & 91.3 & 195.4 & 178.9 & 47.8 & 2.8 & 53.3 & 94.9 & 0.61 & 31.31 & 98.1 & & & \\
\hline & $\min$ & 13.6 & 3.7 & 21.4 & 0.04 & 0.15 & 78.9 & 167.7 & 47.3 & 22.0 & 1.5 & 14.4 & 90.7 & 0.51 & 0.00 & 0.0 & & & \\
\hline & $\max$ & 190.5 & 469.4 & 71.1 & 0.08 & 1.79 & 95.7 & 259.5 & 361.3 & 58.2 & 4.5 & 141.3 & 96.9 & 0.76 & 124.09 & 99.4 & & & \\
\hline & median & 28.9 & 216.8 & 88.2 & 0.06 & 0.51 & 89.5 & 184.9 & 141.8 & 43.4 & 2.9 & 43.5 & 93.8 & 0.60 & 24.94 & 97.7 & & & \\
\hline \multirow{4}{*}{$2 b$} & mean & 42.4 & 2065.9 & 98.0 & 0.18 & 5.87 & 97.0 & 134.1 & 1669.2 & 92.6 & 7.4 & 634.7 & 98.8 & 0.76 & 263.19 & 99.7 & & & \\
\hline & $\min$ & 10.6 & 199.1 & 94.9 & 0.04 & 0.36 & 90.0 & 73.9 & 92.8 & 55.6 & 3.0 & 36.5 & 92.4 & 0.56 & 0.00 & 0.0 & & & \\
\hline & $\max$ & 122.1 & 8411.2 & 98.6 & 0.66 & 21.06 & 97.0 & 195.9 & 6502.1 & 97.1 & 27.8 & 3022.2 & 99.1 & 0.97 & 840.0 & 99.9 & & & \\
\hline & median & 33,0 & 573.3 & 94.6 & 0.13 & 1.81 & 93.3 & 130.9 & 517.5 & 79.8 & 5.6 & 182.8 & 97.0 & 0.76 & 77.3 & 99.0 & & & \\
\hline \multirow{4}{*}{$3 a$} & mean & 53.1 & 370.7 & 87.5 & 0.35 & 2.2 & 86.3 & 244.3 & 196.2 & 44.5 & 7.4 & 29.8 & 80.2 & 0.89 & 35.2 & 97.5 & & & \\
\hline & $\min$ & 37.3 & 66.1 & 63.9 & 0.15 & 0.16 & 51.6 & 179.5 & 0.0 & 0.0 & 2.2 & 0.0 & 0.0 & 0.64 & 0.00 & 0.0 & & & \\
\hline & $\max$ & 91.9 & 1877.3 & 95.3 & 0.73 & 14.21 & 95.1 & 297.2 & 384.7 & 56.4 & 15.7 & 55.5 & 78.0 & 1.23 & 78.82 & 98.5 & & & \\
\hline & median & 47.1 & 139.8 & 74.8 & 0.2 & 0.67 & 77.0 & 259.8 & 153.5 & 37.1 & 5.9 & 25.4 & 81.1 & 0.80 & 27.93 & 97.2 & & & \\
\hline \multirow{4}{*}{$3 b$} & mean & 70.6 & 1016.6 & 93.5 & 1.08 & 6.01 & 84.8 & 234.8 & 1077.6 & 82.1 & 7.0 & 357.5 & 98.1 & 1.05 & 185.07 & 99.4 & & & \\
\hline & $\min$ & 14.2 & 52.9 & 78.8 & 0,00 & 0.16 & 100.0 & 169.1 & 84.1 & 33.2 & 1.7 & 15.6 & 90.3 & 0.64 & 0.00 & 0.0 & & & \\
\hline & $\max$ & 448.2 & 8766.5 & 95.1 & 4.28 & 53.27 & 92.6 & 333.5 & 7898.7 & 95.9 & 10.7 & 3132.3 & 99.7 & 1.59 & 1267.31 & 99.9 & & & \\
\hline & median & 36.9 & 102.5 & 73.5 & 0.74 & 0.61 & 45.2 & 223.8 & 128.9 & 36.5 & 7.3 & 33.2 & 82.0 & 0.94 & 39.85 & 97.7 & & & \\
\hline
\end{tabular}


Table 5: Correlations between trace metals and $\mathrm{Al}, \mathrm{Mg}, \mathrm{Fe}$ in $1 \mathrm{~b}$ in the particulate phase. Trace metals are expressed in $\mathrm{mol} / \mathrm{L}$.

\begin{tabular}{ccc}
\hline trace metal & best fit equation & $\begin{array}{c}\text { correlation } \\
\text { coefficient } \mathrm{R}^{2}\end{array}$ \\
\hline \multirow{3}{*}{$\mathrm{Co}$} & {$[\mathrm{Co}]=4.05 \mathrm{E}-4[\mathrm{Al}]-7.94 \mathrm{E}-11$} & 0.993 \\
& {$[\mathrm{Co}]=1.35 \mathrm{E}-3[\mathrm{Mg}]+3.51 \mathrm{E}-9$} & 0.948 \\
$\mathrm{Cr}$ & {$[\mathrm{Co}]=4.15 \mathrm{E}-4[\mathrm{Fe}]+1.27 \mathrm{E}-8$} & 0.987 \\
& {$[\mathrm{Cr}]=1.07 \mathrm{E}-3[\mathrm{Al}]+2.00 \mathrm{E}-9$} & 0.999 \\
& {$[\mathrm{Cr}]=3.64 \mathrm{E}-3[\mathrm{Mg}]+1.12 \mathrm{E}-8$} & 0.979 \\
$\mathrm{Cu}$ & {$[\mathrm{Cr}]=1.05 \mathrm{E}-3[\mathrm{Fe}]+3.53 \mathrm{E}-8$} & 0.991 \\
& {$[\mathrm{Cu}]=4.44 \mathrm{E}-4[\mathrm{Al}]+1.21 \mathrm{E}-8$} & 0.990 \\
& {$[\mathrm{Cu}]=1.49 \mathrm{E}-3[\mathrm{Mg}]+1.68 \mathrm{E}-8$} & 0.960 \\
$\mathrm{Ni}$ & {$[\mathrm{Cu}]=4.41 \mathrm{E}-4[\mathrm{Fe}]+2.59 \mathrm{E}-8$} & 0.979 \\
& {$[\mathrm{Ni}]=5.24 \mathrm{E}-4[\mathrm{Al}]+5.55 \mathrm{E}-9$} & 0.995 \\
& {$[\mathrm{Ni}]=1.77 \mathrm{E}-3[\mathrm{Mg}]+1.06 \mathrm{E}-8$} & 0.972 \\
$\mathrm{Nb}$ & {$[\mathrm{Ni}]=5.15 \mathrm{E}-4[\mathrm{Fe}]+2.17 \mathrm{E}-8$} & 0.989 \\
& {$[\mathrm{~Pb}]=1.52 \mathrm{E}-4[\mathrm{Al}]+1.55 \mathrm{E}-9$} & 0.996 \\
& {$[\mathrm{~Pb}]=5.14 \mathrm{E}-4[\mathrm{Mg}]+2.94 \mathrm{E}-9$} & 0.979 \\
& {$[\mathrm{~Pb}]=1.48 \mathrm{E}-4[\mathrm{Fe}]+6.25 \mathrm{E}-9$} & 0.986 \\
$\mathrm{H}$ & {$[\mathrm{U}]=5.34 \mathrm{E}-6[\mathrm{Al}]+3.46 \mathrm{E}-11$} & 0.996 \\
& {$[\mathrm{U}]=1.82 \mathrm{E}-5[\mathrm{Mg}]+8.34 \mathrm{E}-11$} & 0.985 \\
$\mathrm{Zn}$ & {$[\mathrm{U}]=5.13 \mathrm{E}-6[\mathrm{Fe}]+1.98 \mathrm{E}-10$} & 0.990 \\
& {$[\mathrm{Zn}]=2.12 \mathrm{E}-3[\mathrm{Al}]+2.16 \mathrm{E}-8$} & 0.994 \\
& {$[\mathrm{Zn}]=7.23 \mathrm{E}-3[\mathrm{Mg}]+4.11 \mathrm{E}-8$} & 0.979 \\
& {$[\mathrm{Zn}]=2.03 \mathrm{E}-3[\mathrm{Fe}]+8.68 \mathrm{E}-8$} & 0.988 \\
\hline \multirow{3}{*}{$\mathrm{N}$} & &
\end{tabular}


Table 6: Correlations between trace metals and $\mathrm{Mg}$ in $2 \mathrm{~b}$ soil solutions in the particulate phase. Trace metals are expressed in $\mathrm{mol} / \mathrm{L}$.

\begin{tabular}{ccc}
\hline $\begin{array}{c}\text { trace metal } \\
\text { in } 2 b\end{array}$ & best fit equation & $\begin{array}{c}\text { correlation } \\
\text { coefficient } R^{2}\end{array}$ \\
\hline $\mathrm{Co}$ & {$[\mathrm{Co}]=1.23 \mathrm{E}-3[\mathrm{Mg}]+1.07 \mathrm{E}-8$} & 0.974 \\
$\mathrm{Cu}$ & {$[\mathrm{Cu}]=1.70 \mathrm{E}-3[\mathrm{Mg}]+4.37 \mathrm{E}-8$} & 0.903 \\
$\mathrm{Zn}$ & {$[\mathrm{Zn}]=8.24 \mathrm{E}-3[\mathrm{Mg}]+4.82 \mathrm{E}-8$} & 0.961 \\
$\mathrm{~Pb}$ & {$[\mathrm{~Pb}]=5.33 \mathrm{E}-4[\mathrm{Mg}]+7.80 \mathrm{E}-9$} & 0.971 \\
$\mathrm{U}$ & {$[\mathrm{U}]=2.23 \mathrm{E}-5[\mathrm{Mg}]+4.03 \mathrm{E}-10$} & 0.942 \\
\hline
\end{tabular}


Table 7: Correlations between Al, POC and trace metals in $2 \mathrm{~b}$ in the particulate phase. Trace metals are expressed in mol/L.

\begin{tabular}{ccccc}
\hline trace metals & best fit equation $(\mathrm{Al})$ & $\begin{array}{c}\text { correlation coefficient } \\
\mathrm{R}^{2}(\mathrm{Al})\end{array}$ & $\begin{array}{c}\text { correlation coefficient } \\
\mathrm{R}^{2}(\mathrm{POC})\end{array}$ \\
\hline $\mathrm{Co}$ & {$[\mathrm{Co}]=3.14 \mathrm{E}-4[\mathrm{Al}]+1.25 \mathrm{E}-8$} & 0.981 & {$[\mathrm{Co}]=7.61 \mathrm{E}-9[\mathrm{POC}]-1.74 \mathrm{E}-9$} \\
$\mathrm{Ni}$ & {$[\mathrm{Ni}]=3.76 \mathrm{E}-4[\mathrm{Al}]+5.46 \mathrm{E}-8$} & 0.980 & {$[\mathrm{Ni}]=1.19 \mathrm{E}-8[\mathrm{POC}]+5.31 \mathrm{E}-9$} \\
$\mathrm{Cu}$ & {$[\mathrm{Cu}]=4.18 \mathrm{E}-4[\mathrm{Al}]+3.86 \mathrm{E}-8$} & 0.994 & {$[\mathrm{Cu}]=1.29 \mathrm{E}-8[\mathrm{POC}]-1.46 \mathrm{E}-8$} \\
$\mathrm{Zn}$ & {$[\mathrm{Zn}]=2.07 \mathrm{E}-3[\mathrm{Al}]+3.52 \mathrm{E}-8$} & 0.989 & {$[\mathrm{Zn}]=4.85 \mathrm{E}-8[\mathrm{POC}]-1.14 \mathrm{E}-8$} \\
$\mathrm{~Pb}$ & {$[\mathrm{~Pb}]=1.37 \mathrm{E}-4[\mathrm{Al}]+6.88 \mathrm{E}-9$} & 0.994 & {$[\mathrm{~Pb}]=3.27 \mathrm{E}-9[\mathrm{POC}]+1.83 \mathrm{E}-9$} & 0.953 \\
$\mathrm{U}$ & {$[\mathrm{U}]=5.54 \mathrm{E}-6[\mathrm{Al}]+3.47 \mathrm{E}-10$} & 0.994 & {$[\mathrm{U}]=1.36 \mathrm{E}-10[\mathrm{POC}]+8.20 \mathrm{E}-11$} & 0.954 \\
$\mathrm{Cr}$ & {$[\mathrm{Cr}]=8.56 \mathrm{E}-4[\mathrm{Al}]+5.50 \mathrm{E}-8$} & 0.993 & {$[\mathrm{Cr}]=2.39 \mathrm{E}-8[\mathrm{POC}]-1.97 \mathrm{E}-8$} & 0.962 \\
\hline
\end{tabular}


Table 8: Correlations between trace metals and $\mathrm{Al}$ in $3 \mathrm{a}$ and $3 \mathrm{~b}$ soil solutions in the particulate phase. Trace metals are expressed in $\mathrm{mol} / \mathrm{L}$.

\begin{tabular}{ccccc}
\hline trace metals & best fit equation in 3a & $\begin{array}{c}\text { correlation coefficient } \\
\mathrm{R}^{2} \text { in } 3 a\end{array}$ & best fit equation in 3b & $\begin{array}{c}\text { correlation coefficient } \\
\mathrm{R}^{2} \text { in } 3 b\end{array}$ \\
\hline $\mathrm{Co}$ & {$[\mathrm{Co}]=3.61 \mathrm{E}-4[\mathrm{Al}]-2.59 \mathrm{E}-10$} & 0.950 & {$[\mathrm{Co}]=2.68 \mathrm{E}-4[\mathrm{Al}]+7.24 \mathrm{E}-9$} & 0.977 \\
$\mathrm{Cr}$ & {$[\mathrm{Cr}]=9.12 \mathrm{E}-4[\mathrm{Al}]-2.32 \mathrm{E}-9$} & 0.963 & {$[\mathrm{Cr}]=8.24 \mathrm{E}-4[\mathrm{Al}]+2.65 \mathrm{E}-8$} & -9.991 \\
$\mathrm{Cu}$ & - & - & {$[\mathrm{Cu}]=3.54 \mathrm{E}-4[\mathrm{Al}]+9.65 \mathrm{E}-9$} & - \\
$\mathrm{Pb}$ & {$[\mathrm{Pb}]=2.77 \mathrm{E}-4[\mathrm{Al}]-1.59 \mathrm{E}-9$} & 0.875 & - & 0.973 \\
$\mathrm{U}$ & - & 0.973 & {$[\mathrm{U}]=8.12 \mathrm{E}-6[\mathrm{Al}]+1.20 \mathrm{E}-10$} & 0.970 \\
$\mathrm{Zn}$ & {$[\mathrm{Zn}]=2.16 \mathrm{E}-3[\mathrm{Al}]-1.35 \mathrm{E}-8$} & & & \\
\hline
\end{tabular}


Table 9: Correlations between elements ( $\mathrm{Mn}, \mathrm{Sr}$ and $\mathrm{U}$ ) and $\mathrm{Ca}, \mathrm{Mg}$ in $3 \mathrm{~b}$ in the particulate phase. Trace metals are expressed in mol/L.

\begin{tabular}{|c|c|c|c|c|}
\hline trace metals & best fit equation $(\mathrm{Ca})$ & $\begin{array}{c}\text { correlation coefficient } \\
\mathrm{R}^{2}(\mathrm{Ca})\end{array}$ & best fit equation (Mg) & $\begin{array}{c}\text { correlation coefficient } \\
\mathrm{R}^{2}(\mathrm{Mg})\end{array}$ \\
\hline $\mathrm{Mn}$ & {$[\mathrm{Mn}]=7.87 \mathrm{E}-2[\mathrm{Ca}]-3.48 \mathrm{E}-5$} & 0.955 & {$[\mathrm{Mn}]=6.21 \mathrm{E}-2[\mathrm{Mg}]-2.11 \mathrm{E}-5$} & 0.844 \\
\hline $\mathrm{Sr}$ & {$[\mathrm{Sr}]=1.64 \mathrm{E}-3[\mathrm{Ca}]+2.70 \mathrm{E}-8$} & 0.919 & {$[\mathrm{Sr}]=1.36 \mathrm{E}-3[\mathrm{Mg}]+2.76 \mathrm{E}-7$} & 0.899 \\
\hline U & {$[\mathrm{U}]=6.76 \mathrm{E}-6[\mathrm{Ca}]-2.91 \mathrm{E}-9$} & 0.849 & {$[\mathrm{U}]=5.20 \mathrm{E}-6[\mathrm{Mg}]-1.69 \mathrm{E}-9$} & 0.758 \\
\hline
\end{tabular}

